\title{
Compilation Framework of Sport Diplomacy Development in Islamic Republic of Iran Armed Forces
}

\author{
Mehr Ali Baran Cheshmeh ${ }^{1}$, Ali Mohammad Safania ${ }^{2}$, Mohsen Bagherian Farahabadi ${ }^{3}$, Salahdin Naqshbandi ${ }^{4}$ \\ 1. Mehr Ali Baran Cheshmeh, (Ph. D Student) Science and Research Branch, Islamic Azad University, Tehran, Iran. \\ 2. Ali Mohammad Safania, (Ph. D) Science and Research Branch, Islamic Azad University, Tehran, Iran \\ 3. Mohsen Bagherian Farahabadi, (Ph. D) Science and Research Branch, Islamic Azad University, Tehran, Iran \\ 4. Salahdin Naqshbandi, (Ph. D) Science and Research Branch, Islamic Azad University, Tehran, Iran
}

\section{ARTICLE INFO}

Received December 2019

Accepted February 2020

\section{KEYWORDS:}

Diplomacy,

Sport Diplomacy,

Armed Forces

\section{CITE:}

Baran Cheshmeh, Safania,

Bagherian Farahabadi,

Naqshbandi, Compilation

Framework of Sport Diplomacy

Development in Islamic Republic

of Iran Armed Forces, Research

in Sport Management \& Motor

Behavior, 2020: 10(20): 174-202

\section{ABSTRACT}

Nowadays, sport provides an opportunity for friendly cooperation among different countries which is based on contribution of all nations and individuals in the natural form of sport. Therefore, the aim of this study was to compile a framework of sport diplomacy in Islamic Republic of Iran armed forces. The methodology of present study is Grounded Theory (GT) having qualitative approach which is applied in terms of purpose using semistructured interviews for data collection. Participants in this study included officials of Ministry of Sport and Youth, the National Olympic and Paralympic Committee, sport federations, sport science professors, foreign ministry experts and great managers of armed forces who aware of sport and public diplomacy which 21 of whom were selected through purposeful sampling. The tool of this research was semi-structured interviews that continued until theoretical saturation stage. The reliability and validity of findings were determined by dependability, reliability and generalizability. Grounded theory qualitative approach was used to analyze the data for open, axial and selective coding. Based on the results, 128 initial conceptual propositions with 31 main categories in six dimensions of paradigm model were identified including causal conditions ( 5 main concepts), contextual factors (6 main concepts), confounding factors (6 main concepts), strategies ( 7 main concepts) and the consequences ( 7 main concepts). The proposed theory was also defined as "Increase the importance of development of military sports diplomacy as a tool for strengthening military diplomacy in other areas of the armed forces' mission and, consequently, the development of public diplomacy of the Islamic Republic of Iran". Finally, it is suggested that the Islamic Republic of Iran Armed Forces pay special attention to sports diplomacy in order to strengthen their mission areas. 


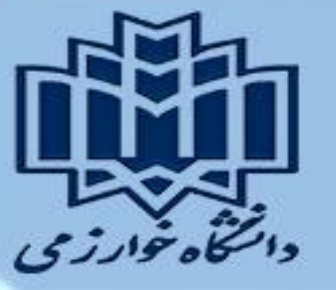

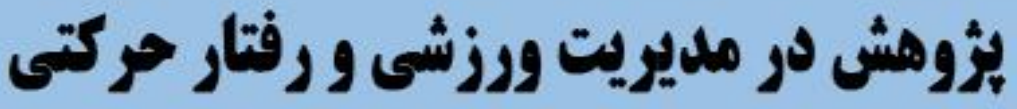

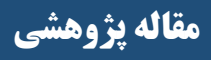

\section{تدوين خار خوب توسعه ديڤماسى ورزش نيروهاى مسلح جمهورى اسلامى ايران}

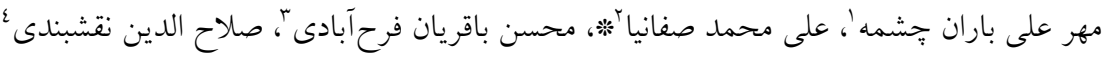 \\ ا. دانشجوى دكترى مديريت ورزشى، واحد علوم و تحقيقات، دانشگاه آزاد اسلامى، تهر ان، ايران

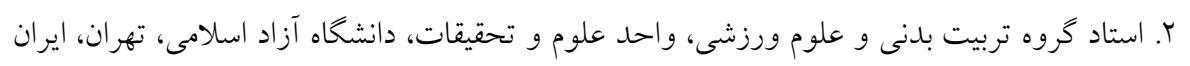

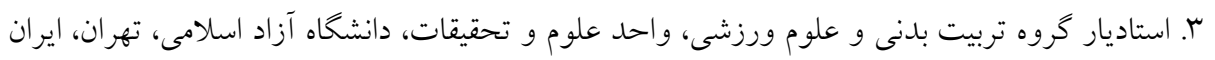

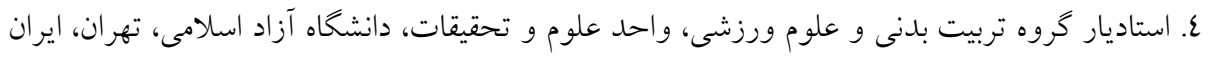

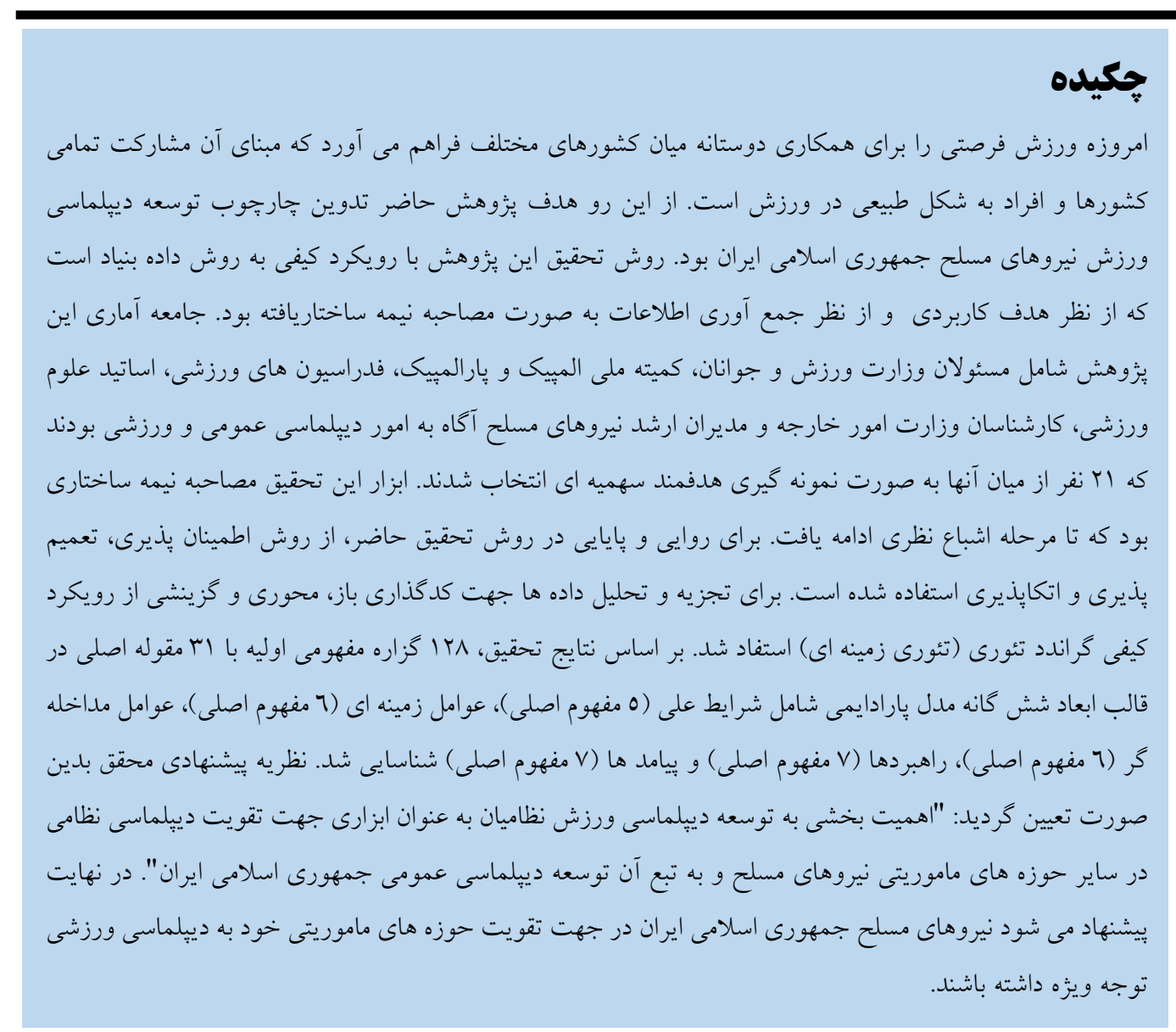

اطلاعات مقاله:

دريافت مقاله دى يهوبا

يذيرش مقاله اسفند 9 بr|

ثقويسنده مسئول:

a.m.safania@gmail.com

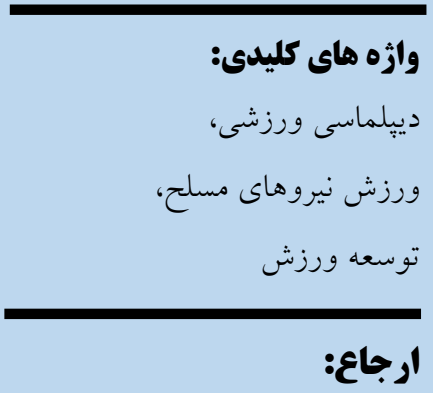

باران جشمه، صفانيا، باقريان فرح

آبادى، نقشبندى. تدوين جارجوب

توسعه ديخلماسى ورزش نيروهاى

مسلح جمهورى اسلامى ايران.

يزوهش در ملديريت ورزشى و رفتار

حركتى، $|V \varepsilon-Y \cdot Y:(Y \cdot)| \cdot \mid$ • 


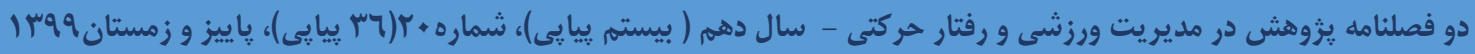

مقـلدمه

دنياى ورزش فرصتى را براى همكارى دوستانه ميان كشورهاى مختلف فراهم مى آورد كه مبناى آن مشاركت تمامى كشورها و افراد به شكل طبيعى در ورزش است. ورزش، افراد و شهروندان جامعه جهانى را تحت يوشش و در كنار يكديخر قرار داده و ميان فرهنگها و قوميت هاى كوناكون ارتباط برقرار مىنمايد. در اين ميان كشورهاى مختلف از ابعاد مثبت ورزش به عنوان رسيدن به اهداف خويش استفاده مى كنند. نقش اوليه ورزش در عرصه سياست بين الملل، مى تو اند به عنوان يك فرآيند دييلماتيك عمومى باشد ( (1). امروزه افكار عمومى يكى از اركان مهم در تصميمگيرى كشورها در حوزه هاى مختلف محسوب مى شود (Y). بنابراين كشورها نمى توانند همجون كذشته تنها بر تبادلات بين دولتى خود در قالب ديبلماسى سنتى تكيه كنند. جرا كه براى تاثير كذارى بيشتر نيازمند برقرارى ارتباط هدفمند با مخاطب عام و به ويزه نخبخان جامعه هستند. از اين رو از روشها و ابزارهاى گوناكون در اين رابطه بهره مى برند. يكى از اين روشهاى دييلماتيك، ارتباط ميان ملت ها است كه تحت عنوان دييلماسى عمومى و يا ديبلماسى مردم محور تبيين شده است. طبق تعريفى كه در سال 1910 توسط وزارت امور خارجه آمريكا منتشر شده است، دييلماسى عمومى به برنامه هاى تحت حمايت دولت اشاره دارد كه هدف آن ها اطلاع رسانى و تحت تاثير قراردادن افكار عمومى در كشورهاى ديخر است (r). دييلماسى عمومى را مى توان يكى از بارزترين ابعاد روابط دييلماتيك در هزاره نوين دانست (ع)؛ با بايان جنگ سرد، شرايط جديد نظام بين الملل باعث شده است تا مؤلفهاى جديدى در ساختار جهانى نسبت به قبل نقش ايفا كنند. در اين ميان اولويتهاى اقتصادى در كنار اولويتهاى امنيتى براى دولتها در عرصه سياست خارجى بسيار براهميت شده اند. از سوى ديخر ظهور بازيخران جديد بين المللى در قالب شركتهاى جند مليتى، سازمانهاى غيردولتى و يا حتى افراد در عرصههاى كوناكون بين المللى كشورها را واداشته است تا در تحقق اهداف و منافع ملى خود از سياستهاى جديد و ابزارهاى جديدى كه منطبق با شرايط كنونى است، استفاده كنند. يكى از مهم ترين اين ابزارها استفاده از ديبلماسى عمومى در دستگاه سياست خارجى است. در اين گونه از ديبلماسى تلاش عمده سياست كذاران، ارتباط با مخاطب عام و نخبخان براى جهت دهى به افكار عمومى است. در همين رابطه در تعريف ديبلماسى عمومى آزانس تبليغات امريكا، اين خونه دييلماسى را درى تودههاى مردم كشور مخاطب، دادن بيام براى آنها، فعاليت به منظور تأثير كذارى بر آنها و توسعه كفت و گو ميان شهروندان و نهادهاى يك كشور از يك سو و نهادهاى كشور ديخر از سوى ديخر مىداند كه اين امر بتواند به

$$
\text { كونهاى باعث تقويت منافع ملى شود (0). }
$$

ديبلماسى عمومى به دنبال برجسته كردن و ارائه منافع ملى به وسيله اطلاع رسانى، درگيرسازى و تحت تاثير قرار دادن مردم در سراسر جهان است و انواع گوناكونى همجون دييلماسى فرهنگى، دييلماسى علمى، دييلماسى ورزشى و غيره را 


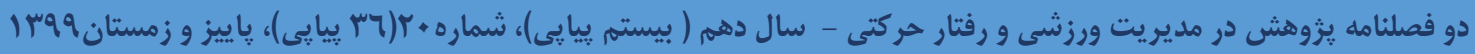

دنبال مى كند. دييلماسى ورزشى رويكردى است كه اخيراً سياستمداران و دولتمردان دنيا با استفاده از افراد و رويدادهاى ورزشى به دنبال ايجاد تصوير مطلوبى از كشور خود در بين سازمان ها و دولت هاى خارجى مى باشند (7). به عبارتى امروزه ورزش به يك جنبه مهمى از نفوذ سياسى دولت ها تبديل شده است (V).. امروزه ورزش و مسابقات ورزشى به طور كسترده اى وارد زندگى خصوصى و عمومى مردم جهان شده است و بر رفتار افراد، جوامع، دولتها و رسانه ها تاثير مى كذارد و يكى از موثرترين ابزارها جهت برقرارى ارتباط براى همه كشورهاست (^). ورزش داراى بيامد سياسى نيز مى باشد كه روابط دولتها و گروههاى اجتماعى را تحت الشعاع قرار مى دهد و با مفاهيمى جون قدرت ملى، رقابت، همخر ايى، واكرايى، سنتز و منازعه، ناسيوناليسم و ملى گرايى، اتحاد و وحدت ملى و نظاير آن بيوند مى خورد و بر نخرش و رفتار دولت ها و ملت ها نسبت به همديخر تاثير مى كذارد. دييلماسى ورزشى به عنوان ابزارى كارآمد و قابل انعطاف در سياست خارجى، زمينه ساز ارتقا روابط دولت ها و به تبع آن افزايش تفاهم ميان ملت ها و كاهش تنش و جنگ و ايجاد صلح و ثبات بين المللى است. امروزه با ناكارآمدى راهكارهاى نظامى در حل مناقشه ها و منازعات جهانى و برقرارى امنيت بين المللى، نياز به استفاده از اين بديده به عنوان راه حلى بنيادين در ميان دولت ها، بيش از بيش احساس مى شود (9). لذا ورزش به عنوان ابزارى در امور بين المللى مورد استفاده قرار كرفته و كشورها مى توانند از آن براى تقويت روابط و ييشبرد برنامه هاى سياسى خود با ديخر كشورها استفاده نمايند. اهميت رويدادهاى بين المللى ورزشى از جمله بازىهاى المبيكى تابستانى، زمستانى و جام جهانى به عنوان بارزترين نوع رويدادهاى دييلماتيك عمومى در جهان امروز، نقش ورزش را بيش از بيش در توسعه تعاملات جهانى از يك سو و تفاوت هاى رفتارى در حوزه سياست خارجى را ير رنخ كرده است. اكثر تحقيقات اعتقاد دارند كه ورزش نقش و كاركردهاى مهمى را در روابط بين الملل و صلح جهانى ايفا مى كند. به عنوان مثال يانى (19 (Y) در رساله دكترى خود به بررسى دييلماسى ورزش در دو كره به منظور تقويت صلح يرداخت. در اين مطالعه محقق تحقيقاتى را از منابع معتبر مختلف براى حمايت از تحقيق خود جمع آورى كرده است. يزوهشخر با انجام مطالعات كتابخانه اى و جستجوى وب سايت به دنبال بررسى موضوع تحقيق خود بود. نتايج اين تحقيق نشان مىدهد كه دييلماسى ورزشى به ابزارى در دييلماسى عمومى تبديل شده است كه توسط كره جنوبى و كره شمالى براى كاهش تنش، حفظ ثبات، آشتى بين دو كشور يذيرفته شده است. بنابراين دو كره به طور مداوم بايد مبادلات ورزشى را در جهت بهبود روابط در شبه جزيره كره انجام دهند( •(1). همجنين ماهنتا و دشپند (19 (Y) در تحقيقى با عنوان "ديبلماسى ورزشى و ارتباط بين المللى: مطالعه موردى هند" عنوان مى كند وقايع ورزشى از زمان هاى قديم بخش جدايى نايذير از تلاشها براى تقويت روابط بين كشورها بوده است. ديبلماسى ورزشى از اشتياق جهانى به ورزش به عنوان راهى براى عبور از اختلافات زبانى و اجتماعى - فرهنكى استفاده مى كند و مردم را به هم بيوند مىدهد. وقايع 


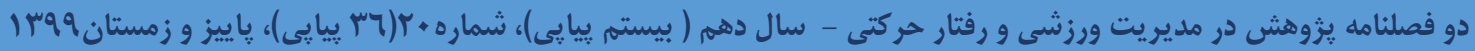

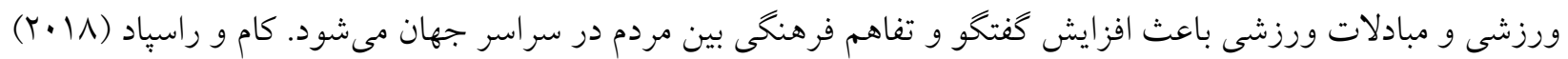
در تحقيقى عنوان كردند ورزش با محوريت ارزشهاى بشردوستانه و توانايى ايجاد اعتماد به نفس، هويت و احساسات، به ابزارى ارتباطى براى اهداف دييلماتيك بسيارى از كشورها (جين ، كره ، روسيه و اخيراً كشورهاى خليج فارس) تبديل شده است. ورزش ابزارى براى ديبماسى، تأثير گذارى و ميانجيكرى است. قطر ورزش را به عنوان يك محور مهم دييلماتيك مورد استفاده قرار داده است تا اين كشور به رسميت شناخته شده و تاييد بين المللى را كسب كند، نقش خود را به عنوان يك قدرت منطقه اى تأييد كند و به امنيت منطقه و خود كمك كند و به نوعى دريجها ايمنى همه منظوره براى كاهش تنش در كوتاه مدت تبديل شود (11).

در روابط بين الملل امروز، دييلماسى نظامى يكى از مهمترين اشكال و فعاليت هاى اكثر دولت هاست. در ادبيات نظرى روابط بين الملل و علم ديبلماتيك، به دييلماسى نظامى در مقايسه با دييلماسى اقتصادى و فرهنكى توجه كمترى شده است. در حوزه مطالعات نظامى نيز، بحث دييلماسى موضوع مطالعاتى كسترده اى نبوده است. از سوى ديخر ورزش بعنوان يك ارزش مشترك ميان تمام انسان ها و جوامع و همجنين ديبلماسى ورزش به عنوان حوزهاى بكر و دست نخورده در تعاملات راهبردى نيروهاى مسلح جمهورى اسلامى ايران مى تواند نقش تعيين كننده اى در تعاملات بين المللى از جمله در حوزه نظاميان داشته باشد؛ از طرفى با توجه به اينكه رابطه ورزش و سياست ارتباطى دو سويه است اين دو مفهوم بر يكديخر تاثير مى كذارند مثلا سياست با تدوين و اجراى راهبرد ورزشى بر ورزش تاثير مى خذارد و ورزش نيز با افزايش هويت ملى و مشاركت اجتماعى بر سياست موثر است. با توجه به اهميت اين دو موضوع و اهميت ورزش بر روابط ديبلماتيك كشورها همجنين روابط دييلماتيك نيروهاى مسلح كشورها، شاهد كم توجهى نيروهاى مسلح به دييلماسى ورزش هستيم. با توجه به اهميت رابطه سياست و ورزش نيازمند شناخت ابعاد بنهان اين بديده هستيم كه از طريق مطالعه اكتشافى و تدوين الكوى راهبردى توسعه دييلماسى ورزشى در نيروهاى مسلح كشور قابل شناخت است. فقدان ملدى جامع در خصوص توسعه دييلماسى ورزشى در نيروهاى مسلح سبب گرديده است تا امروزه رويه ایى ثابت و قابل قبول همخان در اين خصوص ايجاد نخردد. از طرفى برنامهريزى و تصميم گيرى در اين خصوص را نيز تحت شعاع خود قرار دهد كه خروجى آن سبب ناهماهنكى در سياستها و برنامههاى موجود در خصوص دييلماسى ورزشى در نيروهاى مسلح كرديده است. از طرفى با توجه به اينكه يزوهشى در مورد توسعه دييلماسى ورزش در نيروهاى مسلح صورت نخرفته است و بر اساس آنجه عنوان شد و با توجه به كافى نبودن اطلاعات، و همجنين با توجه به اينكه در رساله دكترى بيمانفر (10011)، نيروهاى مسلح به عنوان ذينفعان كليدى در توسعه ديبماسى ورزشى جمهورى اسلامى ايران عنوان شده است، اين يزوهش با هدف تدوين مدلى جهت توسعه دييلماسى ورزشى در نيروهاى مسلح صورت گرفته است. 


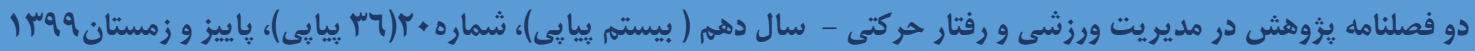

\section{روشـشـناسى}

يزّوهش حاضر از نظر رويكرد كيفى و استراتزى آن از نوع نظريه داده بنياد و از نظر هدف جزء مطالعات كاربردى و از نظر نحوه جمع اورى اطلاعات مصاحبه نيمه ساختاريافته محسوب مى شود. جامعه آمارى اين يزوهش شامل مسئولان وزارت ورزش و جوانان، كميته ملى المبيك و يار المييك، فدراسيون هاى ورزشى، اساتيد علوم ورزشى، كارشناسان وزارت امور خارجه و مديران ارشد نيروهاى مسلح آكاه به امور دييلماسى عمومى و ورزشى بودند كه اب نفر از ميان آنها به صورت نمونه كيرى هدفمند سهميه ایى انتخاب شدند. با توجه به استفاده از روش داده بنياد و انجام مصاحبه براى كردآورى داده ها، نمونه بززوهش به صورت هدفمند انتخاب شد. ابزار يزوهش حاضر، مصاحبه هاى عميق و اكتشافى بود. سوال هاى مصاحبه از نوع بازياسخ بود و بر اساس ابعاد نظريه داده بنياد، عوامل على، شرايط زمينه ای، شرايط مداخله گر، راهبردها و بيامدهاى توسعه ديبلماسى ورزش در نيروهاى مسلح جمهورى اسلامى ايران بررسى تا از زبان مصاحبه شوندكان موضوع روشن شود. روش تجزيه و تحليل داده ها اينكونه انجام گرفت كه ابتدا تيم تحقيق اجازه ضبط مصاحبه را از افراد مورد مصاحبه مى گرفتند و بس از انجام مصاحبه به دقت به مصاحبه هاى انجام شده گوش مى دادند و كدهاى بازى را از مصاحبه استخراج مى كردند. با توجه به ادبيات نظرى يزوهشهاى كيفى، همزمان با انجام مصاحبه ها تحليل و كدگذارى آنها نيز انجام شد. بدين منظور، پس از انجام مصاحبه ها و بياده سازى آنها، متن مصاحبه ها جنندين بار مرور شد تا به كوجكترين واحدهاى تشكيل دهنده و معنادار يا درونمايه تبديل شوند. سيس، براى يافتن مركزيت در بين آنها اين كلمات مرور و بر اين اساس مقوله بندى شدند. سبس، بين متون اوليه و مقولات نهايى جنندين بار مسير استقرايى تكرار شد تا درنهايت، ثبات قابل قبول و مشتركى در بين يزّوهشخران درباره آنجه حاصل از دادهها بود، ايجاد شود. در اين بزوهش، كدگذارى به صورت باز، محورى و انتخابى انجام شد. در كدگذارى باز، يُزوهشگر با مرور مجموعه داده هاى گردآورى شده تلاش كرد كه مفاهيم پپنهانى آنها را باز شناسد. اين مرحله كد گذارى باز ناميده ميشود؛ زيرا، يزوهشخر بدون هيج محدوديتى مقوله ها را نامخذارى ميكند. به بيان ديخر، ئزوهشخر براى تعدد كدها و مقوله ها محدوديتى قائل نميشود. در كدگذارى محورى نيز هدف تعيين رابطه بين مقوله هاى ايجاد شده در مرحلة كدگذارى باز است. استراوس و كوربين كدگذارى انتخابى را به همراه كدگذارى باز و

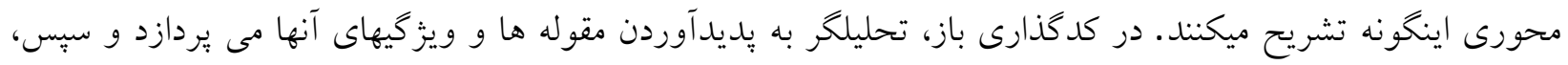
مى كوشد مشخص كند كه جِكونه مقوله ها در طول بُعدهاى تعيين شده تغيير مى كنند. در كدگذارى محورى، مقوله ها، نظام مند بهبود مى يابند و با زيرمقوله ها بيوند داده مى شوند. با اين حال، اينها هنوز مقوله هاى اصلى نيستند كه در نهايت 


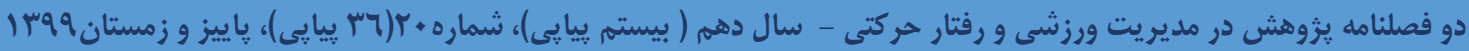

براى تشكيل آرايش نظرى بزركتر يكهيارجه شوند؛ به طوريكه نتايج يزوهش شكل نظريه بيدا كند. كد گذارى انتخابى فرايند يكيار جه سازى و بهبود مقوله ها است (Y I). براى روايى و پيايايى در روش تحقيق كيفى از روش اطمينان يذيرى، تعميم پذيرى و اتكايذيرى استفاده شده است. براى سنجش روايى اين يزوهش، گزارش يايانى فرايند تحليل دادهها و مقوله هاى حاصل شده، به همراه متن مصاحبه براى جهار نفر از مصاحبه شوند كان فرستاده شد و از نظرهاى آنها در كد گذاريها و طراحى الكو استفاده شد كه اين روند حدود سه ماه به طول انجاميد. همجنين، فرايند كد گذارىها توسط دو نفر از استادان صاحب نظر كه عضو گروه مصاحبه نبودند، بررسى شد و بيشنهادهاى آنها در تدوين مدل استفاده كرديد. همجنين از روش توافق درون موضوعى براى محاسبه يايايى مصاحبههاى انجـام گرفته استفاده شده است. براى محاسبه يايايى مصاحبه با روش توافق درون موضوعى دو كدگَذار (ارزياب)، از يكى عضو هيات علمى رشته مديريت ورزشى درخواست شد تــا به عنوان همكار بزّوهش (كد گذار) در يزوهش مشاركت كند؛ آموزشها و تكنيكهاى لازم جهت كدگذارى مصاحبهها به ايشان انتقال داده شد. در هر كدام از مصاحبهها، كدهايى كه در نظر دو نفر هم مشابه هستند با عنوان "توافق" مشخص مىشوند. سيس محقق به همراه اين همكار يزوهش، تعداد سه مصاحبه را كدگذارى كـرده و درصد توافق درون موضـوعى كـه بـه عنوان شاخص يايايى تحليل به كار مىرود با استفاده از فرمول زير محاسبه شد:

$$
\text { ت 100 }
$$

جدول ا، ميزان درصد يايايى بازآزمون

\begin{tabular}{|c|c|c|c|c|}
\hline بِيايى بازآزمون (درصد) & تعداد تو افقات & كل كدها تعداد & عنوان مصاحبه & رديف \\
\hline$\wedge r \%$ & $1 \varepsilon$ & $r \varepsilon$ & $\mathrm{P}_{\mathrm{A}}$ & 1 \\
\hline$\wedge \varepsilon \%$ & 17 & ґ & $\mathrm{P}_{\mathrm{B}}$ & r \\
\hline$V \varepsilon \%$ & $1 \cdot$ & TV & $\mathrm{P}_{\mathrm{C}}$ & $r$ \\
\hline$\wedge 1 \%$ & $\varepsilon$. & 99 & كل & \\
\hline
\end{tabular}




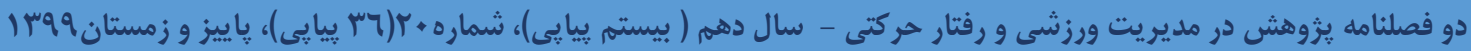

همانكونه كه در جدول ا ملاحظه مى شود تعداد كل كدها در دو فاصله زمانى يك هفته اي برابر 99 ، تعداد كل توافقات

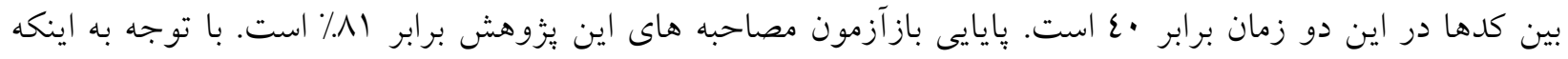
ميزان يايايى بيشتر از •7 ٪ است بنابراين قابليت بايايى كدگذاريها مورد تائيد است.

\section{يافته هاى بزؤهش}

يافته هاى توصيفى بدست آمده در تحقيق مربوط به ويزگگ هاى جمعيت شناختى مصاحبه شوند گان بود كه در جدول r آورده شده است.

جدول r: يافته هاى توصيفى تحقيق (ويزگى هاى جمعيت شناختى مصاحبه شوندگان)

\begin{tabular}{|c|c|c|c|c|c|c|c|c|}
\hline \multicolumn{3}{|c|}{ تحصيلات } & \multicolumn{3}{|c|}{ سابقه مديريت (سال) } & \multicolumn{3}{|c|}{ سن (سال) } \\
\hline دكترى & كارشناسى ارشد & كارشناسى & اسو بالاتر & التا.تا & 1. & اج و بالاتر & 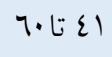 & $\varepsilon \cdot$ r $_{\text {ro }}$ \\
\hline ا 17 نفر & ع ع نفر & ا انفر & و نفر & •ا نفر & r ب كنر & م نفر & ل النفر & r r انفر \\
\hline
\end{tabular}

در اين بخش از نتايج تحقيق مقوله، مفهوم و كويه هاى بدست امده براى شرايط على، عوامل زمينه اى، عوامل مداخله گر، راهبرد و يِيامد بيان مى گردد.

شر ايط علّى مقوله هايى (شرايطى) هستند كه مقولهُ اصلى را تحت تاثير قرار مىدهند و به وقوع يا گسترش بديده مورد نظر مىانجامد. شرايط على در اين تحقيق شامل مفاهيمى بود كه از نشانهاى كد كذارى شده در مورد اهميت يديده اصلى مورد بررسى و نياز و ضرورتى كه براى توسعه ديهماسى ورزش نيروهاى مسلح وجود دارد به دست آمد. توضيحات مصاحبهشوند گان در بِاسخ به سوالات مربوط به شرايط على توسعه ديبلماسى ورزش نيروهاى مسلح، منجر به شناسايى كدهاى جدول r شد. 
جدولr. مفاهيم و گويه هاى شناسايى شده مرتبط با شرايط علّى

\begin{tabular}{|c|c|c|}
\hline كويه & مفهوم & مقوله \\
\hline 1. تقويت ورزش قهرمانى و حرفه اى در جهت كسب افتخار براى معرفى ملت و نيروهاى مسلح كشور & \multirow{9}{*}{ نيروهاى مسلح وجنه و } & \\
\hline r. نشان دادن اقتدار و توانمندى نيروهاى مسلح در ميادين بين المللى ورزشى (سيزم و ...) & & \\
\hline r.r. نشان دادن ظرفيت و توانيى نيروهاى مسلح در ميزبانى رويدادهاى بين المللى ورزشى (سيزم) & & \\
\hline ع. استفاده از ظرفيت بين المللى ورزش براى تشخص و تقويت هويت ملى و اسلامى & & \\
\hline 0. به اهتزاز درآوردن يرجم كشور و نواختن سرود ملى در ميادين بين المللى ورزش & & \\
\hline 7. نشان دادن امنيت عمومى كشور در ميزبانى رويدادهاى ورزشى & & \\
\hline V Vمايش توانمندى كشور ميزبان در برنامه ريزى و بركزارى رويدادهاى ورزشى & & \\
\hline ي. افزايش نغرش مثبت و اعتماد افكار عمومى به نيروهاى مسلح . & & \\
\hline 9. جلو گيرى از تبليغات منفى و در انزوا قرار دادن نيروهاى مسلح ج.|.ايران & & \\
\hline • ا. تاكيد فرماندهى معظم كل قوا مبنى بر حضور موفق و موثر در رويدادهاى بين المللى ورزشى براى سربلندى و اشتهار ملت & \multirow{4}{*}{ 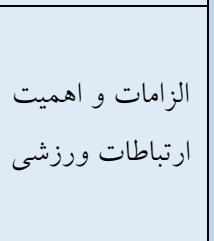 } & \\
\hline 11. اعزام ورزشكاران به رويدادهاى ورزشى به عنوان سفيران انقلاب اسلامى & & \\
\hline r ا. شناخت شايستخى هاى كليدى و توانمندى ورزش نيروهاى مسلح & & \\
\hline rا. انتقال فرهنگ، آداب و رسوم و باورهاى دينى در طول رويدادهاى ورزشى & & \\
\hline ع ا. ورزش به عنوان يك ظرفيت تعامل ساز در سطح بين المللى ـ ع & \multirow{6}{*}{ دييلماسى ورزش } & c. \\
\hline 10. توسعه روابط دييلماسى نظامى بين كشورها با استفاده از روابط ورزشى & & \\
\hline 17. ورزش به عنوان زبان مشترك بين نظاميان به دور از هرگونه اختلافات سياسى و تنش هاى نظامى & & \\
\hline IV كمك به دولت ها در جهت توسعه دييلماسى عمومى از طريق دييلماسى ورزشى نظامى & & \\
\hline 11. دييلماسى ورزش زمينه ساز توسعه دييلماسى نظامى در ساير بخش هاى نيروهاى مسلح & & \\
\hline 19. جلو گيرى و كاهش تنش ها و درگيرى بين نظاميان جهان & & \\
\hline •.Y. علاقه مندى و بروز استعدادهاى جوان در بخش ورزش قهرمانى نيروهاى مسلح & \multirow{3}{*}{ نيازها و انتظارات } & \\
\hline آץ. افزايش اعتماد به نفس ملت و غرور ملى & & \\
\hline r r. افزايش عزت نفس، تقويت اعتماد ملى و عزم و اراده كاركنان نيروهاى مسلح & & \\
\hline rآ. وجود امكانات سخت افزارى و نرم افزارى در بخش هاى تخصصى ورزش نيروهاى مسلح & \multirow{3}{*}{ زيرساخت هاى } & \\
\hline ع r. توليد مبانى نظرى در حوزه قدرت نرم در مراكز علمى و يُزوهشى نيروهاى مسلح & & \\
\hline Tor. جذب سرمايه گزارى بخش هاى اقتصادى دولتى و خصوصى در رويدادهاى ورزشى & & \\
\hline
\end{tabular}

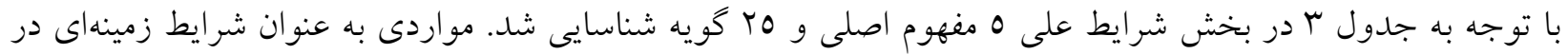
نظر گرفته شدند كه مى توانستند به صورت تخصصى بر راهبردهاى بيادهسازى توسعه دييلماسى ورزش نيروهاى مسلح تاثير بخذارند و بيشتر به محيط داخلى و عوامل در كنترل نيروهاى مسلح مربوط مىشود. توضيحات مصاحبهشوندگان در پاسخ به سوالات مربوط به شرايط زمينهاى توسعه دييلماسى ورزش نيروهاى مسلح، منجر به شناسايى كدهاى جدول ع 


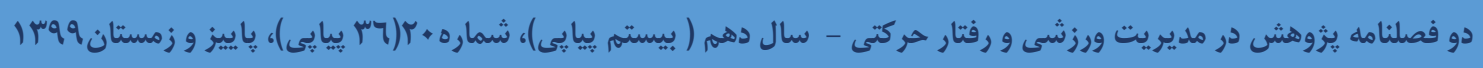

جدول ع. مفاهيم و گويه هاى شناسايى شده مرتبط با شر ايط زمينهاى

\begin{tabular}{|c|c|c|}
\hline كويه & مفهوم & مقوله \\
\hline 1. كسب رتبه و مقام در رويدادهاى بين المللى ورزشى و سيزم & \multirow{3}{*}{ و ختخار آفرينى } & \multirow{21}{*}{$\frac{G}{b}$} \\
\hline r. ديده شدن كشور و شهرهاى ميزبان رويدادهاى ورزشى در سطح دنيا & & \\
\hline ب. تقويت و توسعه صلح و دوستى بين نظاميان كشورهاى مختل & & \\
\hline عُ. وجود ظرفيت هاى بالقوه كشور جهت حضور در رويدادهاى بين المللى ورزش & \multirow{4}{*}{ ظرفيت سازى } & \\
\hline 0. توسعه بسترهاى صنعت كردشخرى در ميزبانى رويدادهاى بين المللى ورزش & & \\
\hline 7. وجود زير ساخت ها، اماكن و تاسيسات ورزشى استاندارد براى رويدادهاى بين المللى ورزش & & \\
\hline V. فراهم بودن بسترهاى مناسب براى حضور ورزشكاران زن محجبه در رويدادهاى بين المللى ورزشى & & \\
\hline ه كسترش همكارى بين سازمانها و نهادهاى ورزشى و غير ورزشى & \multirow{4}{*}{ سازمانل بين } & \\
\hline 9. وجود روابط مستحكم بين دولت و نيروهاى مسلح & & \\
\hline •. •. وجود تعامل و نزديكى بين تربيت بدنى نيروهاى مسلح با وزارت ورزش و جوانان، كميته ملى المييك، فدراسيون هاى ورزشى و ... & & \\
\hline 11. حمايت و بشتيبانى دستكاه هاى دييلماسى كشور در بركزارى رويدادهاى ورزشى & & \\
\hline r rا. وجود ظرفيتهاى بالقوه در نيروهاى مسلح براى تشكيل و اعزام تيمهاى ورزشى جهت شركت در رويدادهاى بينالمللى & \multirow{4}{*}{ 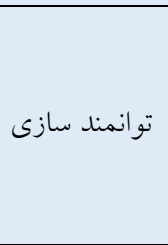 } & \\
\hline rا. داشتن تجربه در بركزارى رويدادهاى بزرگ ورزشى (المبيك، جهانى و ...) & & \\
\hline ع عا. توانمندى در بركزارى اردوهاى مشترى با ساير كشورها در رشته هاى كاربردى (ورزش هاى رزمى، ختربازى و ...) & & \\
\hline 10. برخوردارى از تجربيات ^ سال دفاع مقدس در اعتماد به توان داخلى نيروهاى مسلح & & \\
\hline 17. وجود نيروى انسانى متخصص و مجرب براى شركت در رويدادهاى بين المللى ورزشى (مربى، داور و ...) & \multirow{3}{*}{ نيروى انسانى } & \\
\hline IV آ آموزش مديران ورزشى نيروهاى مسلح براى حضور و فعاليت هدفمند در عرصه دييلماسى ورزشى & & \\
\hline 11. نكرش مثبت فرماندهان و مسئولان نيروهاى مسلح نسبت به توسعه دييلماسى ورزشى & & \\
\hline 19. تدوين برنامه هاى كلان و منسجم در ورزش نيروهاى مسلح & \multirow{3}{*}{ مدرئمه ريزى و } & \\
\hline •T. بهره مندى از كرسى هاى بين المللى در نهادهاى مختلف ورزشى (سيزم و ...). & & \\
\hline آ. جذب، تامين و تخصيص بودجه و اعتبارات مورد نياز براى رويدادهاى بين المللى ورزشى (داخلى و خارجى) & & \\
\hline
\end{tabular}

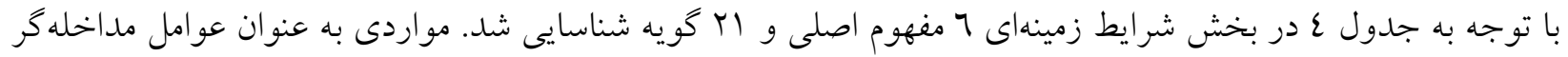
در نظر گرفته شدند كه مىتوانستند به صورت عمومى و با نقش تسهيل كنندگى و محدودكنندگى، بر راهبردهاى بيادهسازى توسعه دييلماسى ورزش در نيروهاى مسلح تاثير بخذارند و بيشتر به محيط كلان و عوامل نخرشى و ذهنى نيروهاى مسلح مربوط مىشود. در تحقيق حاضر مصاحبه شوندگان بيشتر بر عوامل محدود كننده تاكيد داشته و عوامل تسهيل كننده را كمتر ذكر كردند، به همين خاطر عوامل مداخله كر از نوع محدود كننده بيشتر آورده شده است. به عنوان مثال برخى از افراد مصاحبه شونده عواملى از جمله تاكيد رهبر معظم انقلاب بر توسعه دييلماسى ورزش، نخرش و تفكر مثبت مديران و مسئولين ورزشى، وجود زيرساخت هاى ورزشى در برخى از سازمانهاى تابعه نيروهاى مسلح را از جمله عوامل مداخله كر تسهيل كننده برشمردند. توضيحات مصاحبهشوند كان در ياسخ به سوالات مربوط به عوامل مداخله كر توسعه دييلماسى ورزش نيروهاى مسلح، منجر به شناسايى كدهاى جدول 0 شد. 
جدوله. مفاهيم و كويه هاى شناسايى شده مرتبط با شرايط مداخله كر

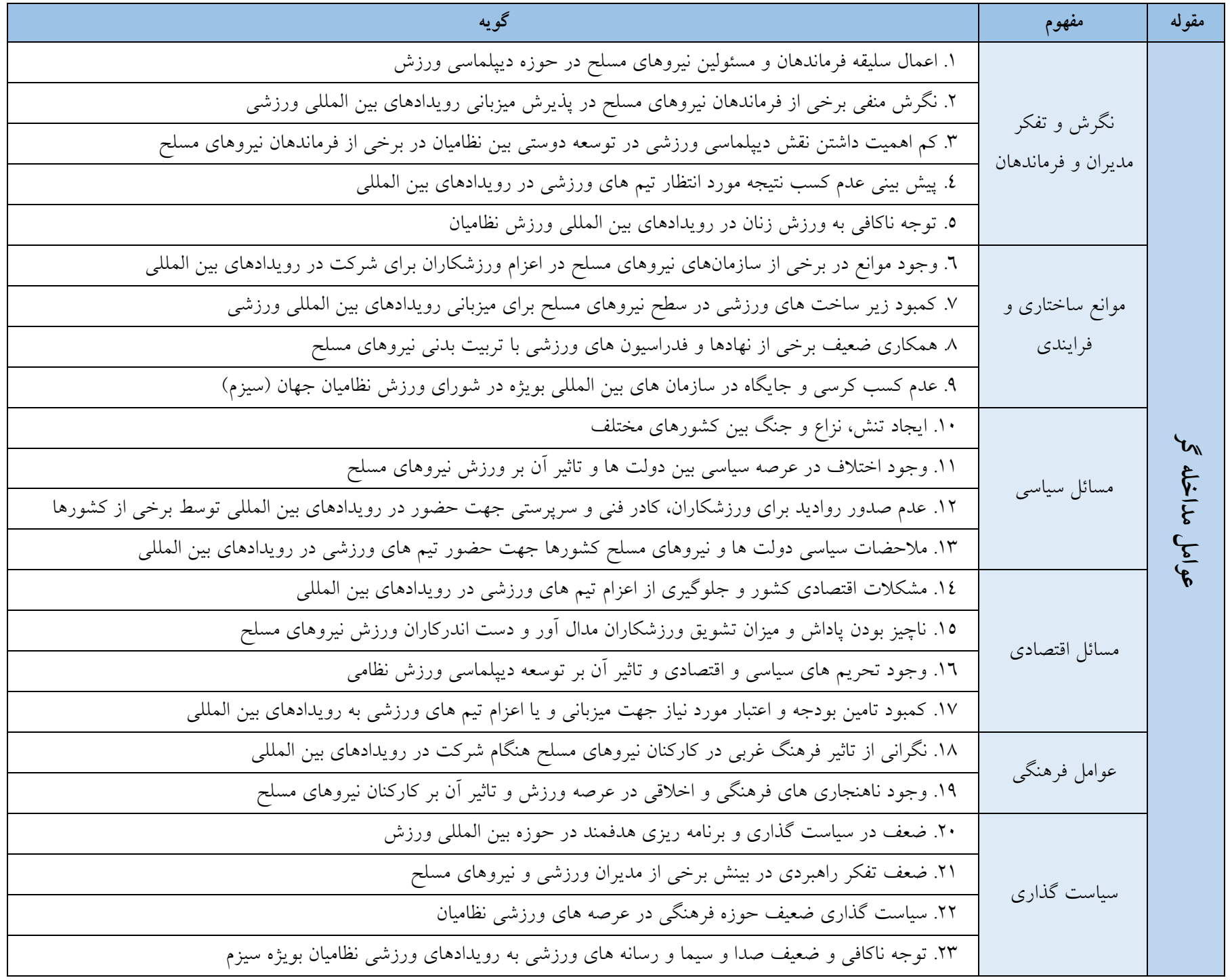

با توجه به جدول 0 در بخش عوامل مداخله گر 7 مفهوم اصلى و بץ كويه شناسايى شد. راهبردها كنشها يا برهم كنش هاى خاصى هستند كه از يديده محورى يعنى توسعه ديبلماسى ورزش نيروهاى مسلح منتج مىشوند و تحت تاثير شرايط زمينهاى و مداخله كر هستند. لذا در اين بخش راهبردهاى مورد نظر براى حل جالشهاى درونى و بيرونى توسعه دييلماسى ورزش نيروهاى مسلح از خبر گان يرسيده شد. توضيحات مصاحبهشوندگان در ياسخ به سوالات مربوط به راهبردهاى موثر بر توسعه ديبلماسى ورزش نيروهاى مسلح، منجر به شناسايى كدهاى جدول 7 شد. 


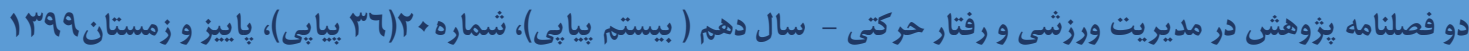

جدول7. مفاهيم و گويه هاى شناسايى شده مرتبط با راهبردها

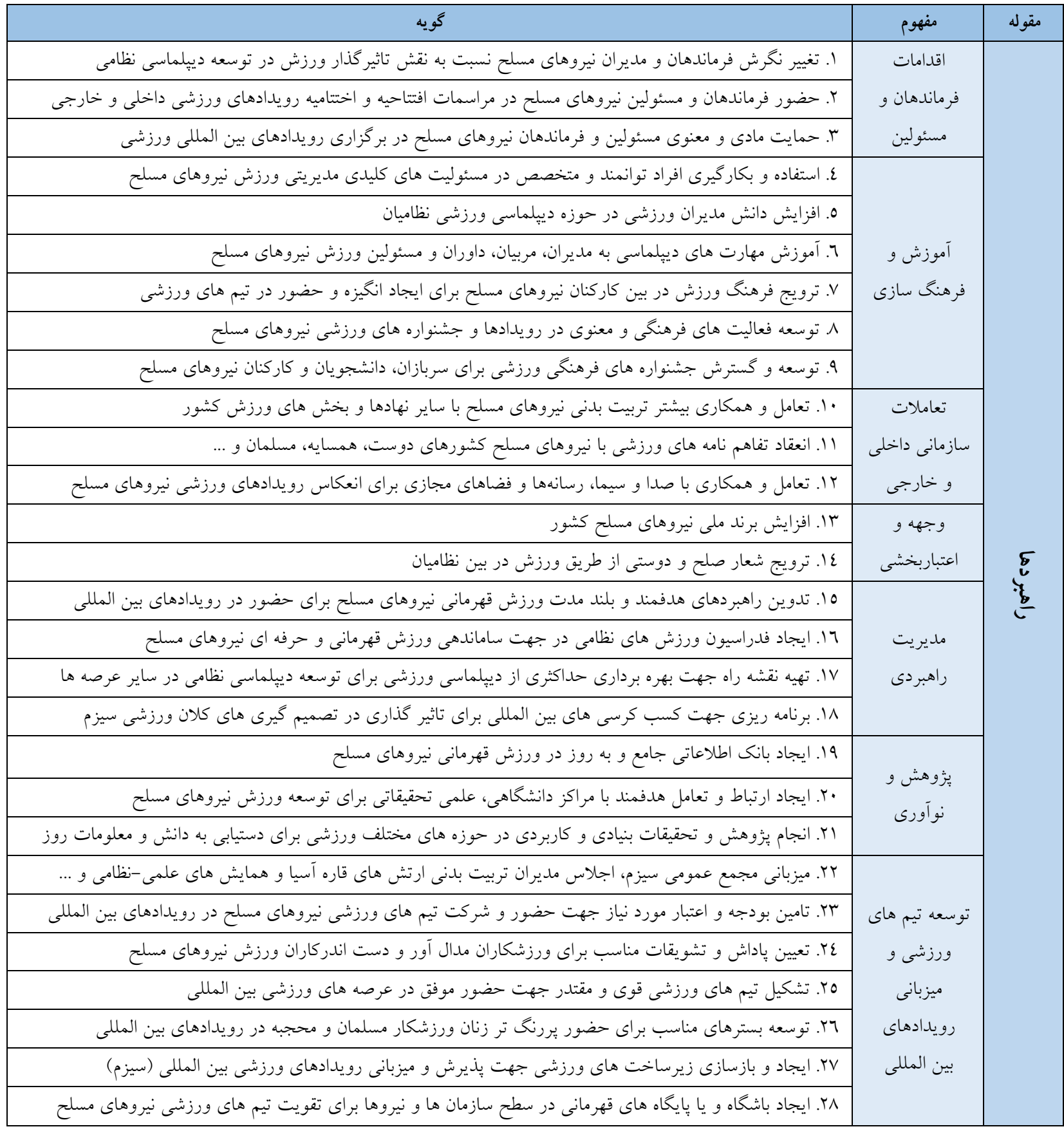

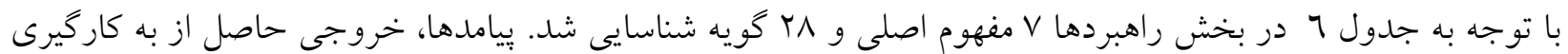
راهبردها هستند. در يايان مصاحبهها از خبر گان يرسيده شد كه با توجه به شرايط درونى و بيرونى بررسى شده و همجنين راهبردهاى ارائه شده يِشبينى مى شود كه جهه بيامدهايى به دست آيد؟ توضيحات مصاحبهشوند گان در پِاسخ به سوالات مربوط به بيامدها منحر به شناسايى كدهاى جدول V شد. 


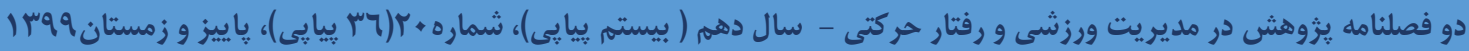

جدولV. مفاهيم و كويه هاى شناسايى شده مرتبط با ييامدها

\begin{tabular}{|c|c|c|}
\hline كويه & مفهوم & 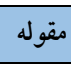 \\
\hline 1. كسترش صلح و دوستى بين نظاميان از طريق ورزش & \multirow{6}{*}{ توسعه صلح، دوستى و } & \\
\hline r. كاهش تنش و دركيرى بين نظاميان و دولت ها & & \\
\hline r. تقويت امنيت عمومى كشور در زمان رويدادهاى بين المللى ورزش & & \\
\hline عـ. افزايش روابط ارزشمند در يحارجوب قوانين ورزشى بين نظاميان ورزشكار & & \\
\hline 0. كاهش تبعيض نزادى بين ورزشكاران در رويدادهاى بين الملى ورزشى & & \\
\hline 7. جمهورى اسلامى ايران بعنوان بر جحم دار صلح و دوستى از طريق ورزش در بين كشورهاى منطقه & & \\
\hline V. افزايش عزت نفس و غرور ملى با موفقيت در عرصه هاى بين المللى ورزش نظاميان & \multirow{11}{*}{ دستاوردهاى فرهنكى و } & \\
\hline ^ـ ايجاد تصوير مثبت در اذهان جامعه نسبت به كاركنان و ورزشكاران نيروهاى مسلح & & \\
\hline 9. سربلندى و اشتهار ملت با موفقيت در رويدادهاى بين المللى ورزش نظاميان & & \\
\hline •l. نمايش تو انايى ملت، دولت و نيروهاى مسلح در عرصه هاى بين المللى ورزش & & \\
\hline 11. انتقال فرهنگ، آداب و رسوم و سنت هادر رويدادهاى بين المللى ورزشى ل & & \\
\hline r I. افزايش همكارى و تعامل بين نيروهاى مسلح و ساير وزارتخانه ها و نهادهاى ورزشى & & \\
\hline سا. تصوير مثبت از كشور ميزبان در اذهان شركت كندكان ساير كشورها & & \\
\hline ع ا. كسترش و تقويت هويت ملى با موفقيت در عرصه هاى بين المللى ورزشى & & \\
\hline 10. فرصت براى تبليغ كشور ميزبان در رويدادهاى بين المللى ورزشى & & \\
\hline 17. خننى نمودن تبليغات سوء دشمنان با حضور فعال در عرصه هاى بين المللى ورزش & & \\
\hline IV ا. ورزشكاران نيروهاى مسلح به عنوان سفير ان انقلاب اسلامى در ميادين بين المللى ورزشى & & \\
\hline 11. افزايش سطح سلامت، نشاط، شادابى و آمادگى جسمانى عمومى كاركنان نيروهاى مسلح & \multirow{3}{*}{ كاركنان نيروهاى مسلح جسمانى } & \\
\hline 19. استفاده از ظرفيت صدا و سيما و رسانه هاى ورزشى براى تبليغ و نشان دادن توان نيروهاى مسلح & & \\
\hline •r. نمايش توانمندى و آمادگى جسمانى و روحى نظاميان با موفقيت در عرصه هاى ورزشى & & \\
\hline آT. ايجاد ظرفيت هاى جديد در حوزه ورزش قهرمانى نيروهاى مسلح در تعامل با ساير كشورها & \multirow{3}{*}{ توسعه ورزش قهرمانى و } & \\
\hline TY. بهبود جايكاه ورزش زنان در عرصه هاى ملى و بين المللى ـ ـ & & \\
\hline rrr. توسعه ورزش قهرمانى نيروهاى مسلح جهت كسب رتبه و مقام هاى برتر در رويدادهاى بين المللى ورزشى & & \\
\hline عَ. توسعه صنعت گردشكرى در زمان بركزارى رويدادهاى بين المللى ورزشى (المبيك، جهانى، سيزم و ...) & \multirow{3}{*}{ توسعه زيرساخت هاى } & \\
\hline 0T. توسعه و بازسازى زيرساخت هاى شهرى، تاسيسات و اماكن ورزشى در ميزبانى رويدادهاى بين المللى ورزش & & \\
\hline דr. افزايش مهارت و تجربه در بركزارى رويدادهاى ورزشى جهانى، المييك، سيزم و ... & & \\
\hline TV TV. ايجاد تعامل با نيروهاى مسلح ساير كشورها در عرصه هاى ديخر نظامى & \multirow{3}{*}{ توسعه تعاملات بين } & \\
\hline يץ. ايجاد فرصت مناسب براى ملاقات با مسئولان و فرماندهان نيروهاى مسلح ساير كشورها & & \\
\hline وq. ايجاد زمينه مناسب جهت عقد تفاهم نامه هاى ورزشى بين مديران تربيت بدنى كشورهاى مختلف & & \\
\hline •r. إيجاد زمينه مناسب جهت ارتباط دولت ها و كاهش انزواى سياسى & \multirow{2}{*}{ تحريم هاى اقتصادى } & \\
\hline اب. كاهش تحريم هاى اقتصادى از طريق ارتباطات ورزشى & & \\
\hline
\end{tabular}

https://jrsm.khu.ac.ir/ 
با توجه به جدول V در بخش بيامدها V مفهوم اصلى و اس گويه شناسايى شد. در اين مدل راهبردها به كونهاى تنظيم شدهاند كه در توسعه ديبلماسى ورزش نيروهاى مسلح واكنش درستى به شرايط على، عوامل زمينهاى و مداخله شود كه در اين صورت ييامدهايى كه بِ از اعمال راهبردها به دست مى آيند، برونداد راهبردها محسوب مىشوند. براى بهبود فرايند طبقهبندى كدها در قالب مقولهها، ابزار مقايسههاى نظرى به وسيله استراوس و كوربين بيشنهاد شده است. براين اساس، א| ا كد مستخرج نهايى در قالب اسمفهوم دسته بندى شده است. كد گذارى انتخابى، كد كذارى محورى را در سطحى بالاتر و انتزاعى تر ادامه مى دهد. در اين مرحله شكل كيرى و بييوند هر دسته بندى با ساير كروه ها تشريح مى شود. در اين مرحله محقق بيشتر در نقش نويسنده ظاهر مى شود كه براساس مقولات، نوشته هاى كدگذارى، يادداشت هاى نظرى، شبكها و دياكرامها عمل مى كند. جهت گيرى كدگذارى گزينشى

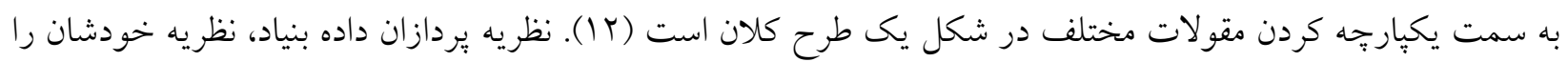
در سه شكل ممكن ارائه مى دهند: ا- يك الكوى كد گذارى بصرى ، ؟- مجموعه اى از قضايا (يا فرضيهها)، ب- داستانى

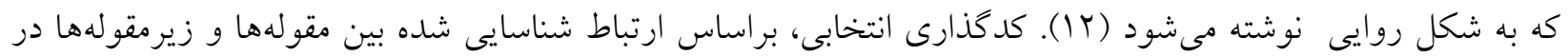
كد گذارى باز و محورى، شروع مىشود.

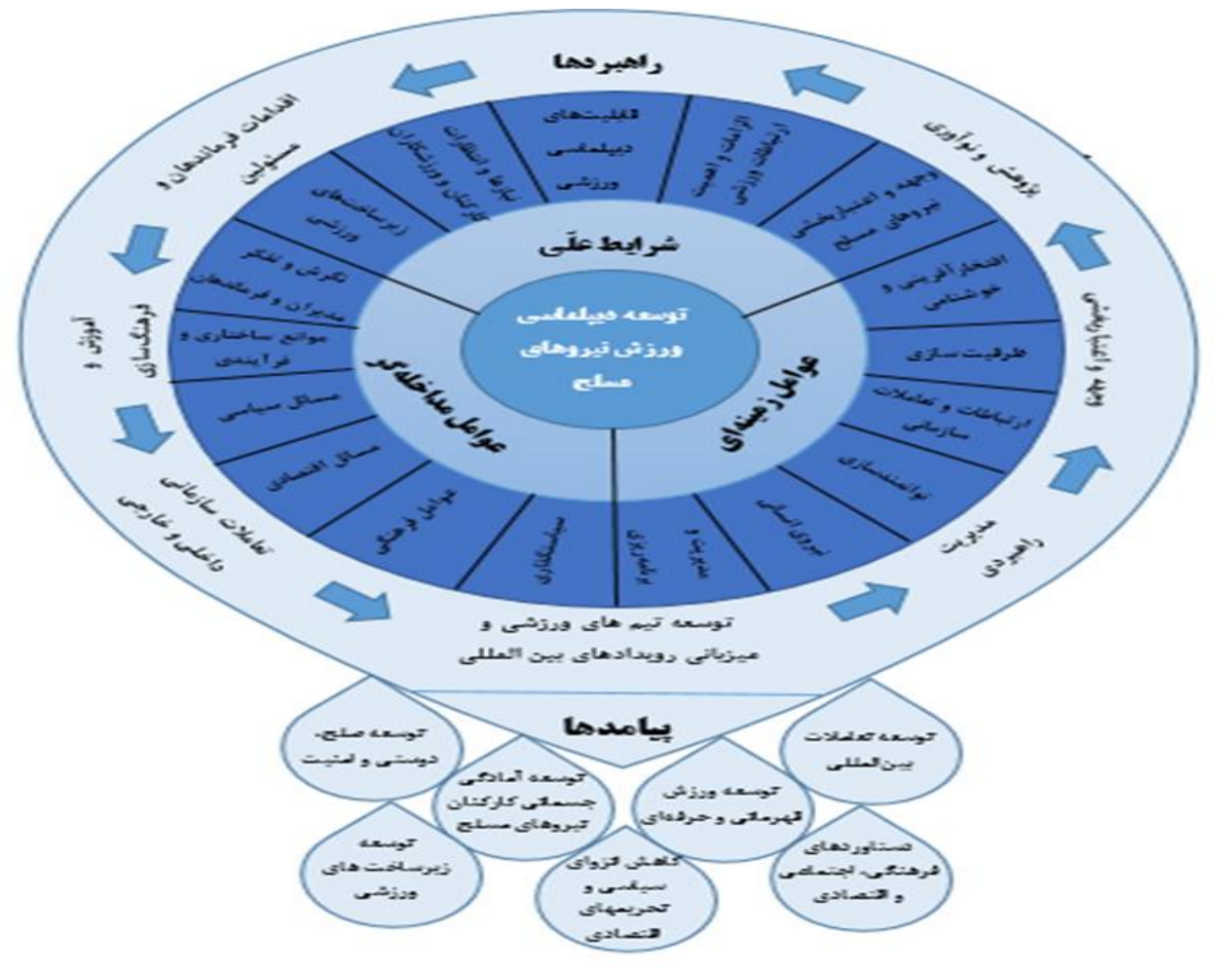

شكل 1: الكوى بيشنهادى توسعه دييلماسى ورزش در نيروهاى مسلح بر اساس يافته هاى اين يزوهش 


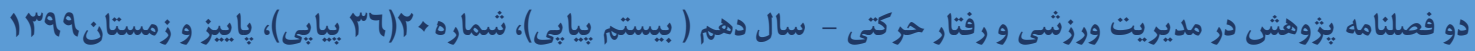

در مدل ارائه شده در شكل شمارهُ يك، اس مفهوم اصلى درقالب ابعاد شش كانهُ مدل يارادايمى شامل عوامل على (0) مفهوم)، شرايط زمينه اى (T مفهوم)، شرايط مداخله كر (T مفهوم)، راهبرد (V) مفهوم) و ييامدها (V مفهوم) براى توسعه دييلماسى ورزش در نيروهاى مسلح را نشان مى دهد. با عنايت به گزاره ها، مفاهيم و مقوله هاى تحقيق، در نهايت نظريه بيشنهادى تحقيق به شرح زير تعيين كرديد: "اهميت بخشى به دييلماسى وززش نظاميان به عنوان /بزارى جهت تقويت دييلماسى نظامى در سا ير حوزه هاى ماموريتى نيزوهاى مسلح و به تبع آن توسعه دييلماسى عمومى جمهورى اسلامى "يران"

\section{بحث و نتيجه تيرى}

يزوهش حاضر به تدوين مدل توسعه ديبلماسى ورزش در نيروهاى مسلح برداخته است. بدين منظور، از روش نظرئ. داده بنياد براى ارائه الكو استفاده شد و مدل ارائه شده از فرايندهاى كدگذارى ناشى از مصاحبه با نخبخان به دست آمد. نتايج تحليل دادههاى كيفى حاصل از مصاحبه، ارائهُ مدل يارادايمى توسعه دييلماسى ورزش با اس مقولة اصلى و 1Y مقولة فرعى درقالب ابعاد ششخانه شامل عوامل على (0 مفهوم)، شر ايط زمينه اى (7 مفهوم)، شر ايط مداخله كر (7 مفهوم)، راهبرد (V) مفهوم) و ييامدها (V مفهوم) بود. در اين مدل، وجهه و اعتباربخشى نيروهاى مسلح، الزامات و اهميت ارتباطات ورزشى، قابليت هاى ديبلماسى ورزشى، نيازها و انتظارات كاركنان و ورزشكاران، زيرساخت هاى ورزشى به عنوان عوامل على در نظر گرفته شده اند. اين عوامل بر توسعه دييلماسى ورزش در نيروهاى مسلح اثر مى كذارند و توجه به نقش هر كدام از آنها در كاركرد مدل ضرورى است. نتايج اين بخش از تحقيق با نتايج شريعتى و كودرزى (1)، (1)، ييمانفر و

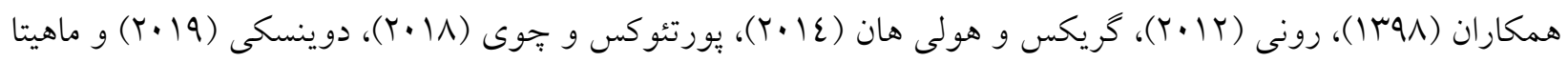

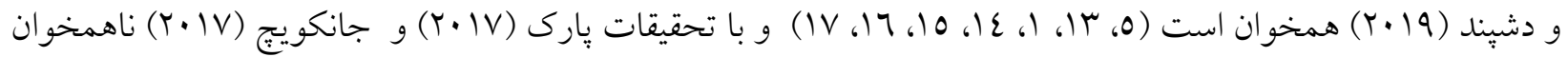
است (1)، 19). در تحقيقات ناهمخوان ذكر شده، اهميت وجهه و اعتبار بخشى و ارتباطات ورزشى بسيار ناجيز عنوان شده و آنها را عواملى مهم جهت توسعه دييلماسى ورزشى ذكر نكرده اند. در حال حاضر تحولى شخرف در عرصه دييلماسى رخ داده است. تحولى كه باعث شده است اهميت قدرت نرم افزايش يافته و جايخزين قدرت سخت شود. وجهه و اعتبار كشورها همجنين نيروهاى مسلح كشورها نوعى قدرت نرم محسوب مى شود. اساسا كاركرد دييلماسى ورزشى آن است كه با در نظر كرفتن ارزشهاى ملى كشورها، موجبات جذب كروههاى مردمى، بهبود وجهه و اعتبار كشورها را فراهم مى كند. رهبر معظم انقلاب اسلامى در اين مورد مى فرمايند "شماها (در ميادين بين المللى) بيام هايى را مى رسانيد كه اين ييام ها با هيج وسيله اي قابل رساندن نيست، يِام عزم و اراده، بيام ايستادكى و بيام ايمان. ايشان مى 


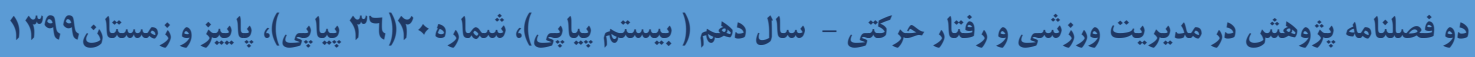

فرمايند ورزش از موجودى ملت ها خبر مىدهد و سخن مى گويد، حتى از توانايى دولتها هم خبر مىدهد و حرف مىزند". امروزه دولت ها، كشورها و سازمانها به دنبال راهكارهايى هستند تا خود را كشورى با وجهه و اعتبار نشان دهند. نيروهاى مسلح جمهورى اسلامى ايران نيز از اين قاعده مستثنى نيست و به دنبال بهبود وجهه و اعتبار خود در سطح منطقه و جهان است. معمولا ورزش و رويدادهاى مهم ورزشى مى تواند تاثير قابل توجهى در وجهه و اعتبار يك كشور در سطح ملى و بين المللى داشته باشد، مثلا مسابقات جام جهانى فوتبال 7 +. ب در آلمان و بازى هاى المبيكى زمستانى در

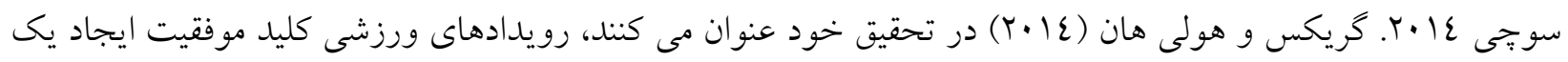
تصوير مثبت جهت رسيدن به اعتبار است. همجنين كريكس عنوان كرد كه آلمان و روسيه از طريق بر گزارى بازى هاى

جام جهانى فوتبال و المٍيك زمستانى اعتبار كسب كرده اند (ع (). در جهان كنونى اهميت ارتباطات رو به افزايش اســت. كسـترش ارتباطات و تعاملات بين ملت ها در انواع و ســطوح متفاوت موجبات صـسلح را فراهم كرده و به حفظ آن كمك مى كند و ورزش در اين مســير با توجه به اينكه زبانى بين المللى دارد و انســانها را جداى از مرزها در كنار يكديخر جمع مى كند يكى از مناســب ترين ابزارها اســت. از طريق ورزش بيام هاى صـــلح و دو ستى آ سان تر انتقال بيدا مى كند (N). عامل ديكرى كه به عنوان شرايط على در تو سعه دييلما سى ورز شى نيروهاى مسلح تعيين شد قابليت هاى دييلما سى ورزش بود. براى درى بهتر قابليت هاى دييلماسى ورزش بايد ابتدا قابليت هاى ورزش را درى كرد. اولين نقشـى كه مى توان براى ورزش در حوزه روابط بين الملل

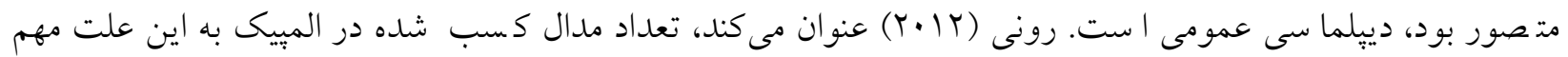
است كه مشروعيت سيا سى را به دنبال دارد. ميزان تاثير وتمايل ر سانه ها براى يو شش اخبار رويدادهاى بين المللى و تاثير آن بر افكار عمومى حاكى از موثر بودن ورزش در عرصـه سـياسـت و دييلماسـى اسـت (1). از ديخر شــرايط و مقولههاى جهانى كه نقش توسـعه ديبماسـى ورزشسى نيروهاى مسـلح را بررنخ كرده اسـت نيازها و انتظارت كاركنان نيروهاى مسلح است. اهميت روزافزون اين عامل باعث شده تا اين عامل در زمره شرايط على توسعه دييلماسى ورزش در نيروهاى مـ سلح از نظر نخبخان همكارى كننده در تحقيق تعيين شود. سازمانهاى موجود در هر جامعه با ا ستفاده از منابع محدودى كه در اختيار دارند، به گونه اي به رفع نيازهاى فردى و گروهى افراد جامعه مىيردازند و از آنجا كه منابع توليد همواره با يك ويزً گى يعنى كميابى مواجه هستند، اغلب اصلى ترين هدف سازمانها استفاده بهينه از عوامل توليد و رسيدن به اثربخشى است. اين عوامل شامل زمين، سرمايه، نيروى اذسانى، فناورى و مديريت است. در اين بين نيروى ان سانى ارز شمندترين دارايى سازمان هاى و از حسا سيت بالايى برخوردار ا ست. يكى ديخر از مفاهيمى كه در بخش شرايط على از اهميت قابل توجهى برخوردار است، نيازها و انتظارات كاركنان ورزشكار نيروهاى مسلح مى باشد. وجود 


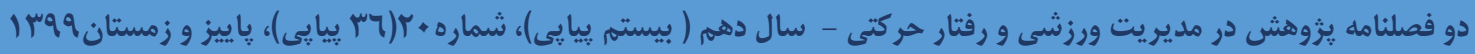

نيروهاى جوان و با انخيزه در نيروهاى مـ سلح از يك سو و علاقه آنان به شركت در رويدادهاى ورز شى جهت كسب افتخار، سبب مى شود تاعزم و اراده ملى و اعتماد به نفس كاركنان افزايش يافته و اين امر غرور ملى را با خود به همراه خواهد داشت. توسعه زيرساخت هاى ورزشى از جمله ايجاد اماكن و تاسيسات ورزشى، تامين تجهيزات و لوازم سخت و نرم افزارى در بخش هاى تخصــصـى ورزش و انجام تحقيقات و يزوهش هاى علمى و كاربردى در مراكز علمى تخصصى ورزشى و جذب سرمايه گذارى بخش هاى اقتصادى دولتى و خصو صى در بركزارى رويدادهاى ورزشى از مسائل مهم در مقوله شرايط على محسوب مى گردد. بنابراين توسعه زيرساختها، امكانات و تجهيزات ورزشى از جمله بيامدهايى است كه براى تو سعه ديّما سى ورز شى فعال مى تواند براى هركشورى مفيد واقع شود. بدون ترديد وجود زيرسـاخت هاى ورزشىى مناسـب، موجبات ميزبانى رويدادهاى ورزشسى را فراهم نموده و منجر به توسـعه دييلماسـى ورزشى مى شود.

عوامـل زمينـهاى توسـعه دييلماسـى ورزشـى در نيروهــاى مســلح در تحقيـق حاضــر افتخــار افرينسى و خوشـنامى، ظرفيـت سـازى، ارتباطـات و تعـاملات سـازمانى، توانمندسـازى، نيـروى انسـانى، مـــيريت و برنامـهـ ريـزى تعيـين

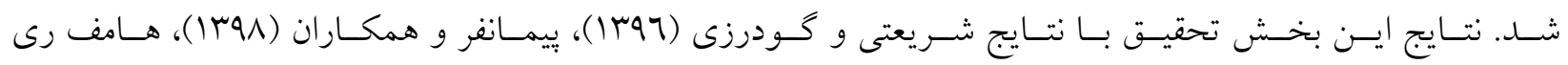

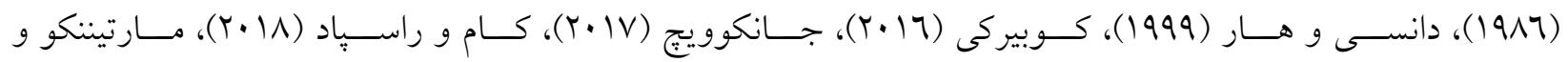
همك كــاران (19) افتخار و خوشنامى در سازمانها و جوامـع مختلـفـ امـرى مهـم اسـت كـه سـازمانها و جوامـع بـه دنبـال دسـتيابى بـهـ

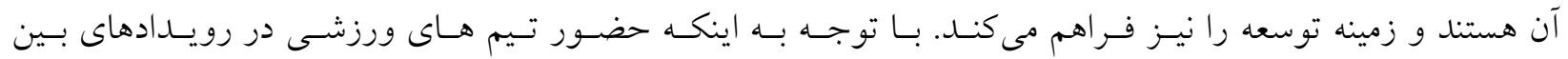

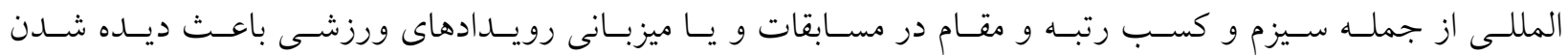
شـهر و كشـور ميزبـان در سـطح جهـان مسى شـود زمينسه سـاز افتخـار آفرينسى و خوشـنامى بــراى جوامـع محسـوب

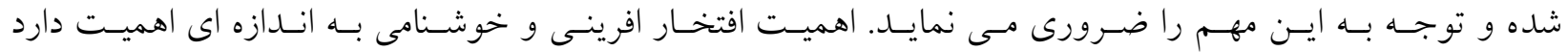

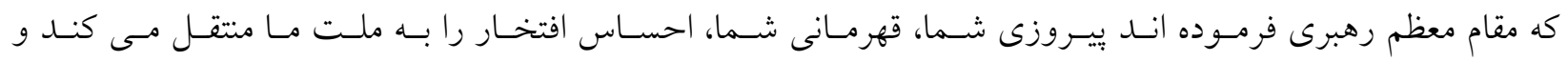

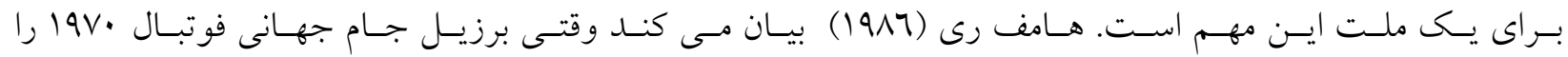

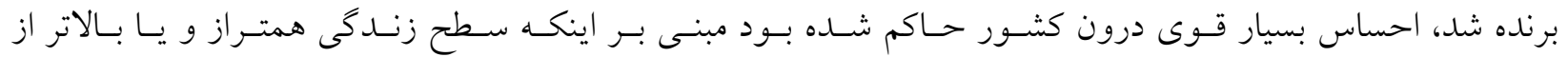
كشورهاى جهان اول بود و آنهـا احسـاس مسى كردنـــ كـه كشورشـان در جوامـع بـين المللسى شـاخص و سرشـناس

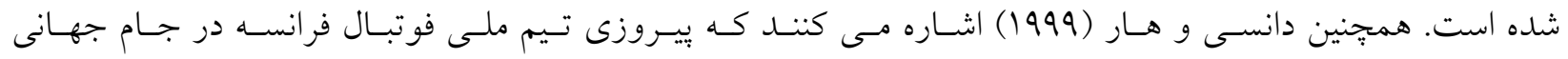




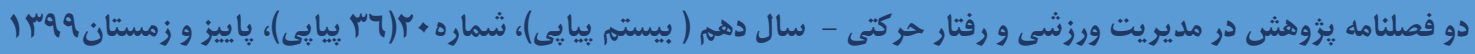

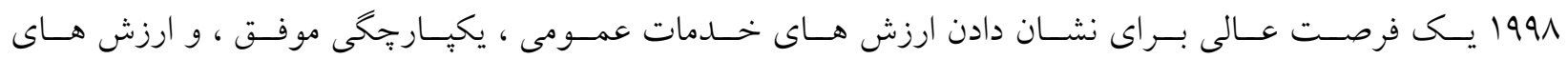
سنتى آنان در عرصه بين المللى بود كه اين عوامل موجبات خوشنامى كشور فرانسه را فراهم نمود.

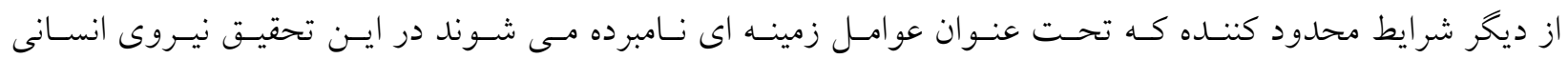

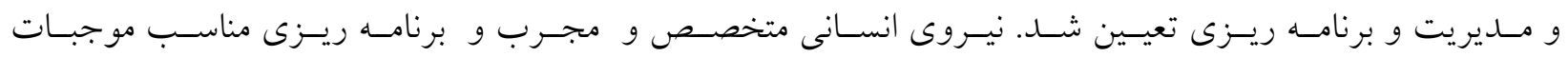
توسـعه ديبلماسـى ورزشـى در نيرهــاى مسـلح را فــراهم ميكنـــ و عكسـ آن نيـز از ســرعت توسـعه دييلماسـى

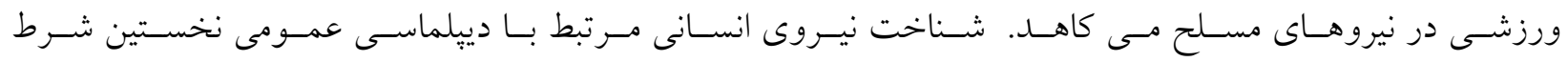

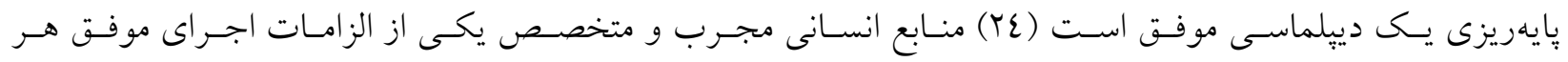

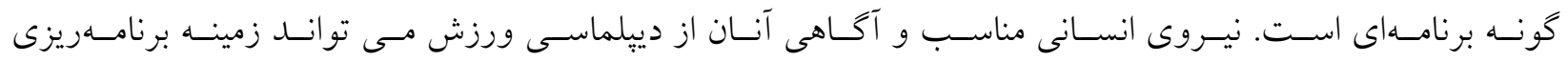

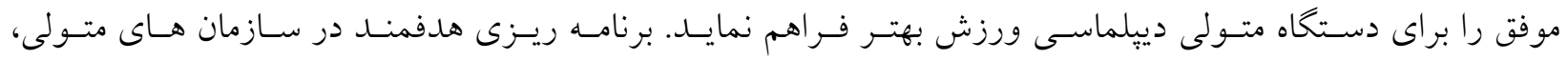
زمينه توسعه مناسـب تـر ديبلماسـى ورزش را فـراهم مسى كنــ. منـابع انسـانى نقـش بررنخسى در توسـعه سـازمانها و

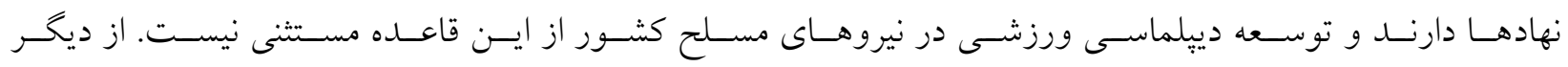
شـر ايط زمينـه اي در ايسن تحقيـق ارتباطـات و تعـاملات بـين سـازمانى تعيسين شـد. بـين ارتباطـات و تعـاملات بـين

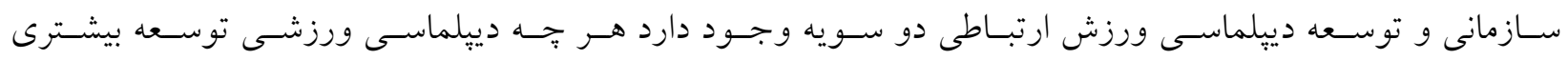

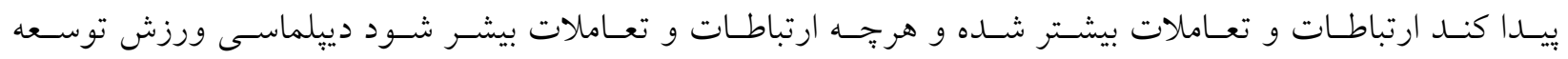

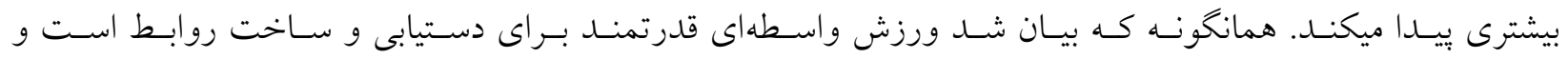
ارزشهـايى همجِـون احتـرام متقابـل، تســاهل، شـفقت، نظــم، ايجــاد فرصـت برابــر و حكمرانسى قـانون را ميــان

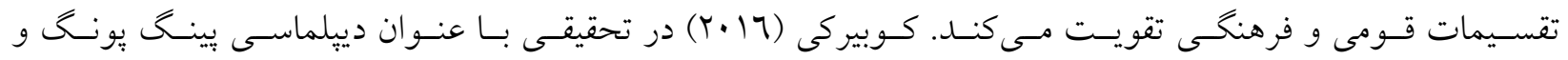

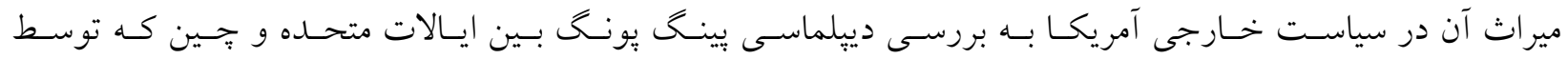

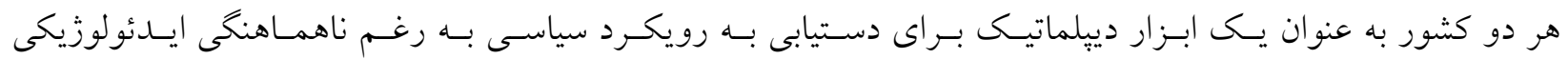
و اختلاف بـر سـر تـايوان و ارتبـاط بـين دو كشـور، مـورد اسـتفاده قــرار كرفـت يرداخـت. هـر دو دولـت بـه دنبـال راهى براى ايجاد روابط نزديـك بودنـد، امـا شـرايط خـاص آنهـا را از تمـاس هـاى دييلماتيـى سـنتى منـع مسى كـرد.

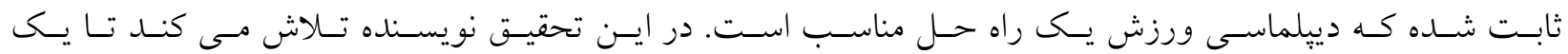

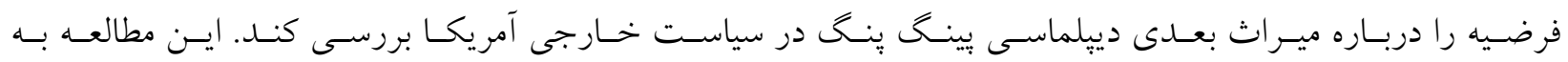
منظور تعيين دلايـل نيـاز بـه اسـتفاده از ورزش بـهـ منظـور ايجــاد روابـط نزديـى تـر بـين بــازيخران متخاصـم روابـط 


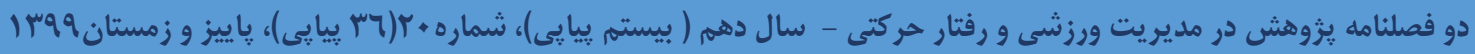

بــين الملـل انجـام شـــ نتـايج ايسن تحقيـق نشـان داد دييلماسـى ورزش توانـايى بهبـود ارتباطـات كشـورهاى داراى

تنش سياسى را دارد (YY).

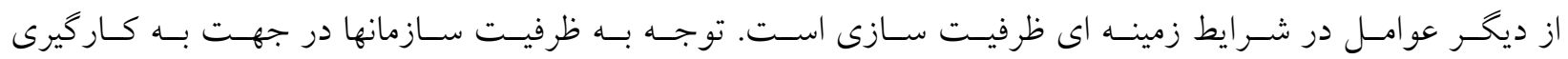
دييلماسـى ورزش زمينـه سـاز توسـعه دييلماسـى ورزش مسى شـود. توجـهـ بـه ظرفيـت نيروهـاى مسـلح در جهـت

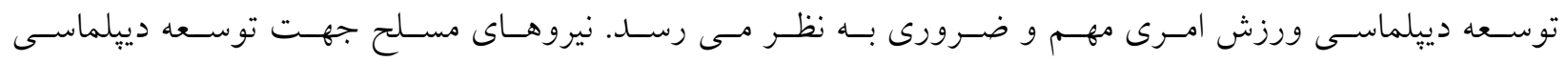
ورزشى بايســــــهــــواردى از جملـه، وجـود ظرفيـت هـاى بـالقوه كشـور جهـت حضـور در رويــادهاى بـين المللسى ورزش، توسعه بسـترهاى صـنعت كردشـحرى در ميزبـانى رويــادهاى بـين المللـى ورزش، وجـود زيــر سـاخت هـا، اماكن و تاسيسـات ورزشـى اسـتاندارد بــراى رويــادهاى بــين المللـى ورزش، فــراهم بــودن بسـترهاى مناسـب بـــاى

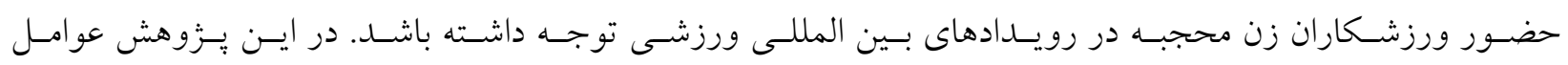

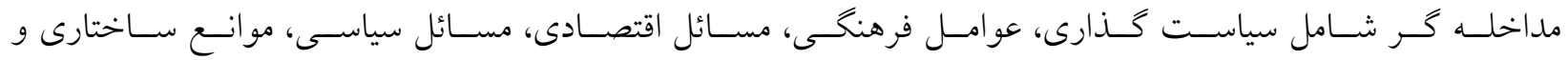

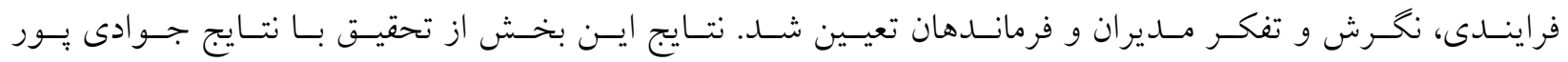

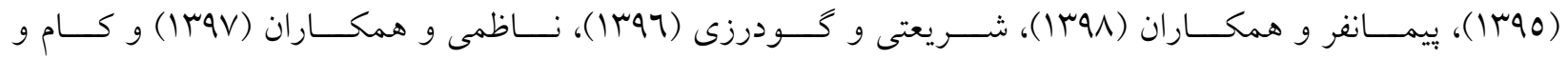

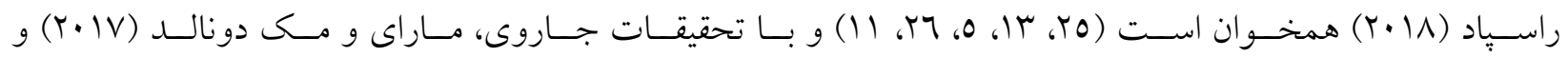

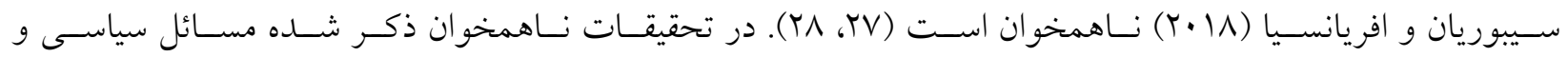

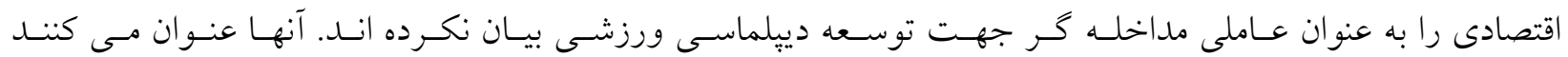

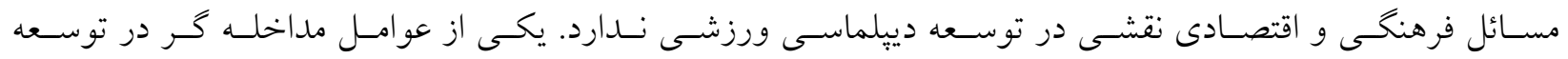
دييلماسـى ورزش در نيروهـاى مسـلح سياسـت گــذارى اسـت. در واقـع سياسـت گــذارى نامناسـب و همجنــين

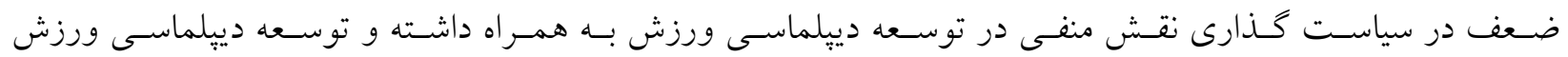

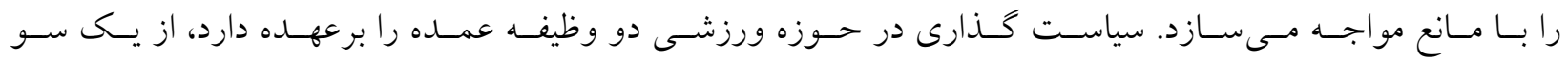

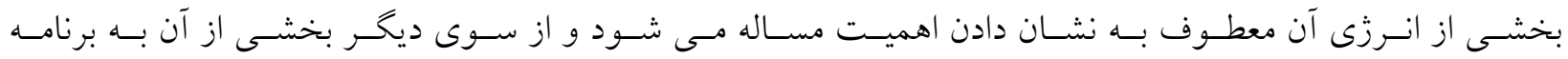

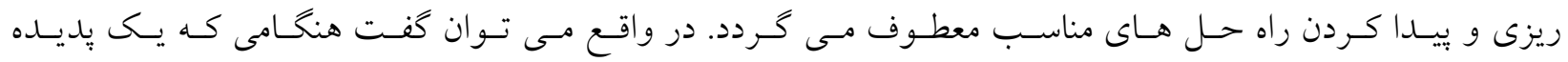

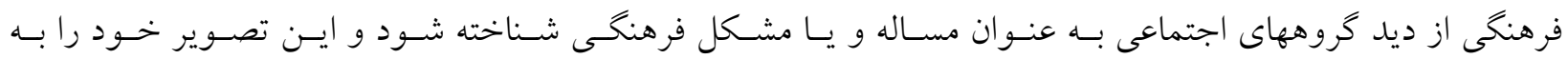
صورت يك فشار اجتماعى نشـان دهـد، اراده لازم بــراى حـل مشـكل بـهـ شـكل سـاده تـرى بسـيج مسى شـود امـا بـــ

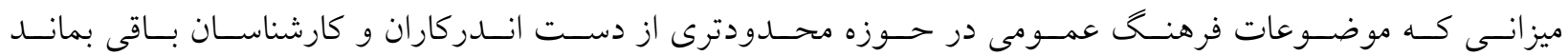

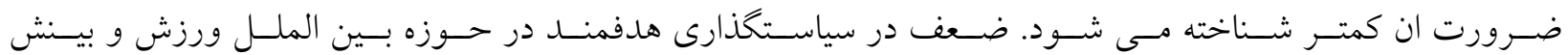
https://jrsm.khu.ac.ir/ 


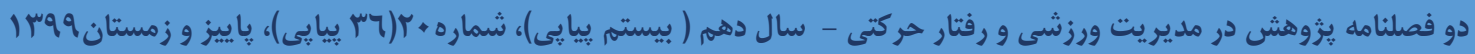

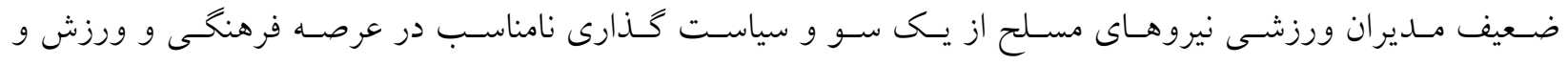
بى تـوجهى صــا و سـيما و رسـانه هـاى ورزشسى بـه رويـادهاى ورزشسى نظاميـان جهـان (سـيزم) از سـوى ديخـر، مى تواند تاثير منفى را در توسعه دييلماسى ورزش نيروهاى مسلح به همراه داشته باشد. از ديخــر عوامـل مداخلـه گــــ در توسـعه دييلماسـى ورزشـى در نيروهــاى مسـلح مســائل اقتصـادى اسـت. مســائل

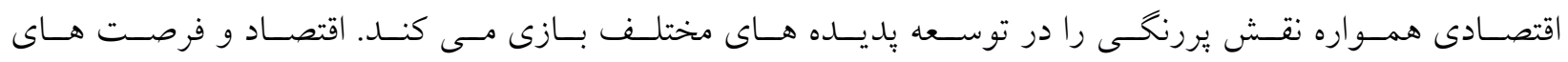
اقتصـادى عـاملى مهـم در توسـعه و كسـترش ديهماسـى ورزشـى محسـوب مسى شـوند. در صـورتى كـه ايسن ابـزار

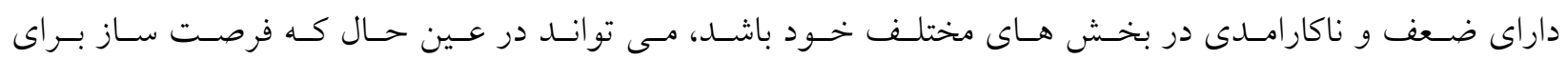

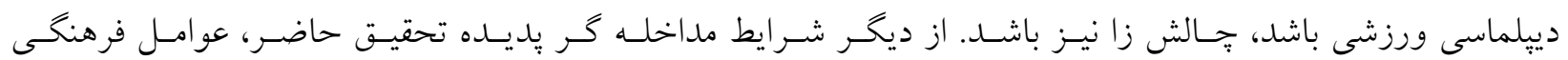

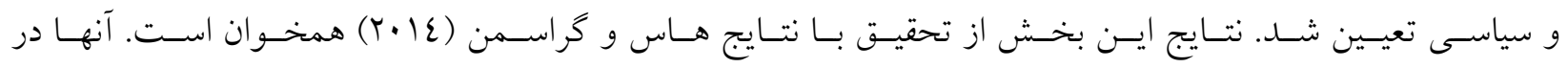

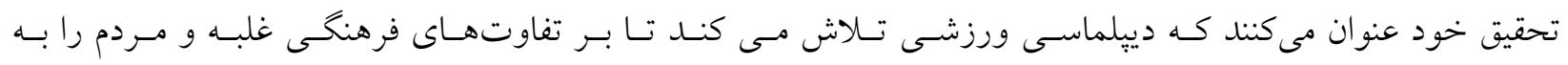

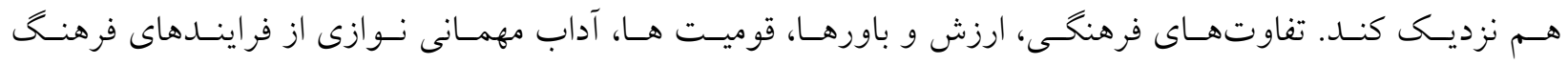
سازى اسـت كـه مسى توانــ عـلاوه بــر نزديـك كـردن مـردم بـهـ هــم، ارتباطـات دييلماتيـك قـوى تـرى را بـهـ دنبـال

داشته باشد (Yq).

از عوامـل مداخلـهـ خـر در توسـعه ديبلماسـى ورزشسى در نيروهـاى مسـلح در تحقيـق حاضـر، موانـع سـاختارى و فرايندى بـود. نخبخـان در تحقيـق حاضـر، بـهـ وجـود موانـع در برخسى از سـازمانهـاى نيروهـاى مسـلح از جملـه در

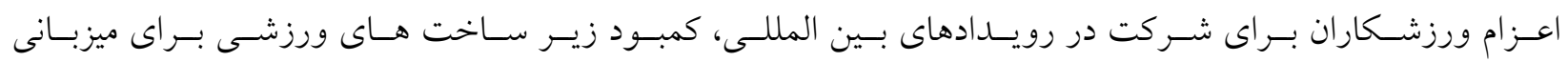

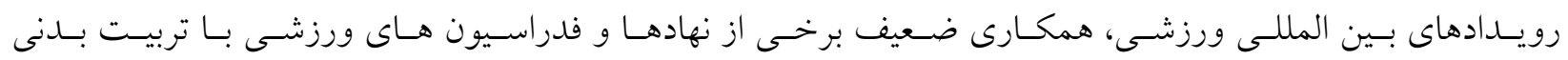
نيروهــاى مســلح، عـــم كسـب كرسـى و جايخـاه در سـازمان هـاى بـين المللـى بـويزه در شـوراى ورزش نظاميـان

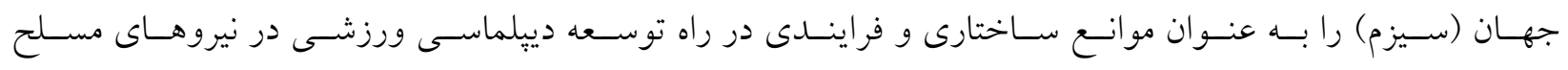
برشمردند. نيروهاى مسلح جهت توسعه بيشتر دييلماسى ورزشى بايد بر موانع فوق فائق آيد.

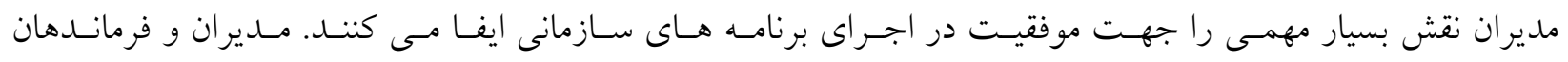

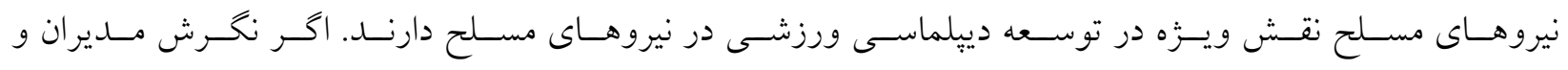
فرمانـدهان نيروهــاى مســلح بـه توسـعه دييلماسـى ورزشسى مثبـت باشــ موجبـات توسـعه ايسن بديــده در نيروهـاى

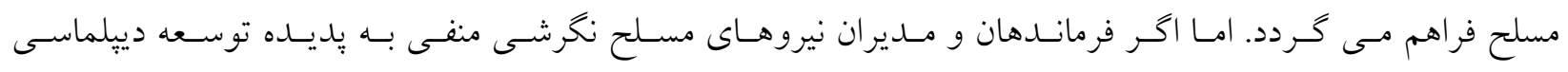

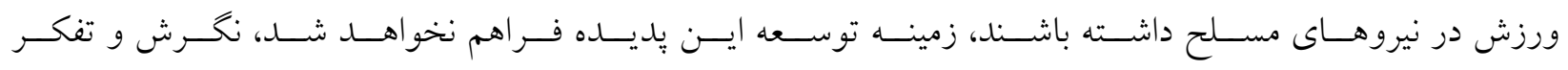




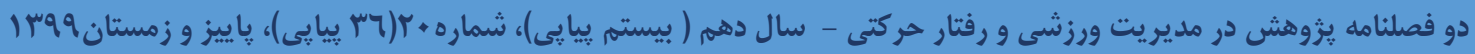

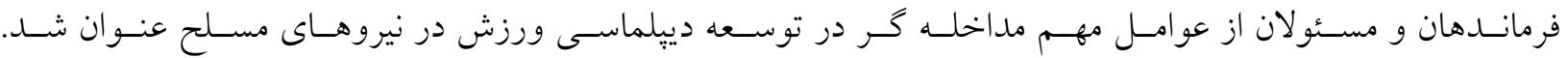

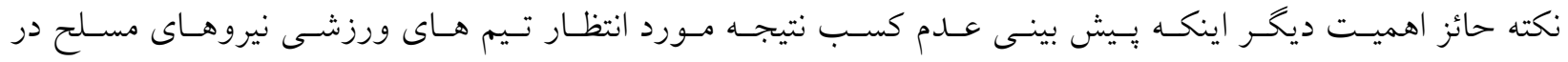
رويدادهاى ورزشى و توجه ناكافى بـه حضـور زنـان در رقابـت هـاى ورزشـى بـين المللـى و سـيزم از ديخــ عوامـل مداخله گر در توسعه دييلماسـى ورزشسى نيروهـاى مسـلح نـام بـرده شـده اسـت. همجنـين برخسى از افـراد مصـاحبه

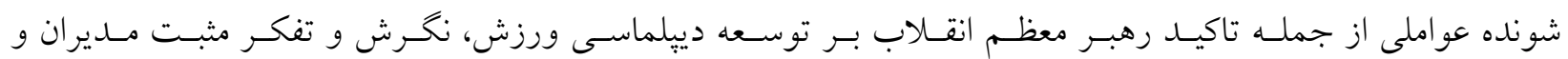
مسـئولين ورزشـى، وجـود زيرسـاخت هـاى ورزشسى در برخـى از سـازمانهـاى تابعـه نيروهـاى مسـلح را از جملـهـ عوامل مداخله گر تسهيل كننده برشمردند.

آنجهه در اين بخش از مدل به عنوان راهبردهاى توسعه دييلماسى ورزشى نيروهاى مسلح مدنظر صاحب نظران بود شامل اقدامات فرماندهان و مسئولين، آموزش و فرهنگ سازى، تعاملات سازمانى داخلى و خارجى، توسعه تيم هاى ورزشى و ميزبانى رويدادهاى بين المللى، مديريت راهبردى، وجهه و اعتبار بخشى و بيزوهش و نوآورى بود. نتايج اين بخش از

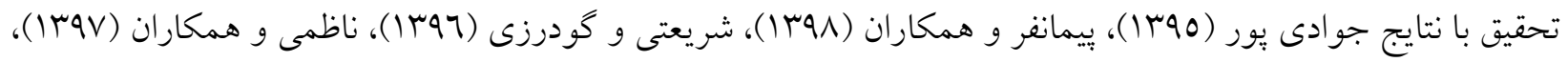

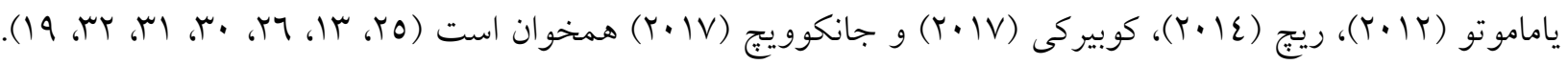
از جمله راهبردهايى كه جهت توسعه دييلماسى ورزش نيروهاى مسلح در اين تحقيق مشخص شد اقدامات فرماندهان و مسئولين بود. فرماندهان و مسئولين در نيروهاى مسلح عاملى مهم در توسعه دييلماسى ورزش نيروهاى مسلح به شمار مى روند و مى تو انند با اقدامات مناسب خود موجبات توسعه دييلماسى در نيروهاى مسلح را فراهم كنند. ياماموتو (Y (Y) نقش و جايگاه ورزش در سياست ملى زاين را مورد تجزيه و تحليل قرار داد. وى در تحقيق خود با عنوان "توسعه ملت ورزشى: ورزش را به عنوان يك حوزه استراتزيك سياست ملى زاين" بيان مى كند كه جنبش سياسى با اقدام قانونخذارى جديد براى ورزش كشور زاين ضرورت دارد. همجنين ياماموتو ضمن بيان رشد علاقه و برجستكى سياسى و دولتى در ورزش نقش ساختارى مديران ورزش زإِن را تشريح مى كند. در بايان اين تحقيق بيان شده است كه در حال حاضر مفهوم توسعه از طريق ورزش به منظور بنا نهادن يك دولت بر يك فرهنگ ورزشى قوى در دستور كار دولت زاين قرار دارد كه مديران ورزش زاين نقش مهمى در اين فرايند بر عهده دارند و نوى بيكان ايجاد اين فرهنگ ورزشى محسوب مى شوند. آموزش و فرهنگ سازى از ديخر راهبردهاى توسعه دييلماسى ورزش در نيروهاى مسلح است. آموزش و فرهنگسازى عموما نقش مهمى در توسعه يديده هاى مختلف ايفاء مى كند. جيزى كه توسط نخبخان تحقيق حاضر به عنوان راهبردى جهت توسعه دييلماسى ورزش به آن اشاره شد. نخبشان تحقيق حاضر به عو املى مانند استفاده و بكار گيرى افراد توانمند و متخصص در مسئوليت هاى كليدى مديريتى ورزش نيروهاى مسلح، افزايش دانش مديران ورزشى در 


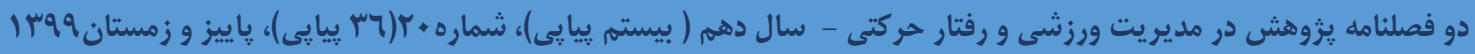

حوزه دييلماسى ورزشى نظاميان، آموزش مهارت هاى دييلماسى به مديران، مربيان، داوران و مسئولين ورزش نيروهاى مسلح، ترويج فرهنگ ورزش در بين كاركنان نيروهاى مسلح براى ايجاد انگيزه و حضور در تيم هاى ورزشى، توسعه فعاليت هاى فرهنكى و معنوى در رويدادها و جشنواره هاى ورزشى نيروهاى مسلح، توسعه و كسترش جشنواره هاى فرهنگى ورزشى براى سربازان، دانشجويان و كاركنان نيروهاى مسلح اشاره كردند. از ديخــر راهبردهــاى توسـعه ديبلماسـى ورزش در نيروهــاى مســلح كـه در ايسـن تحقيـق مشـخص شـــ تعـاملات

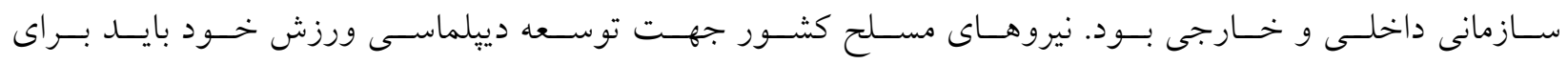

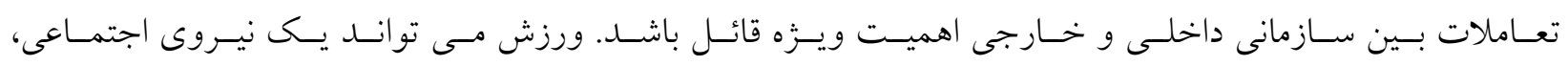

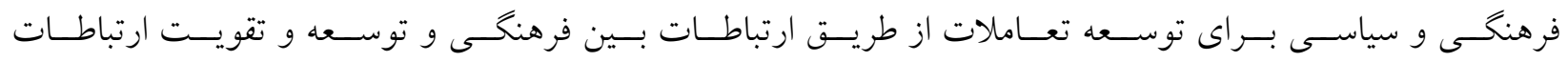
اجتماعى و سياسى باشد. ورزش يكى ابـزار بسـيار مفيـد بــراى هـر كشـورى كـه در عرصـه روابـط بـين الملـل در گيـر

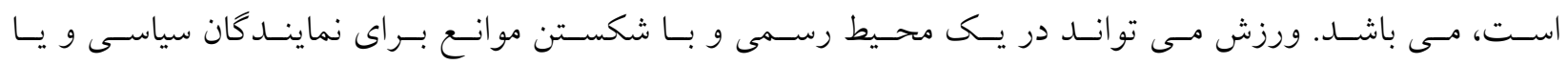
سـازمان هـاى غيـر دولتسى در منـاطق بحــران بـهـ روابـط كشـورها كمـك كنـــ و موجبـات تعـاملات بيشـتر كشـورها

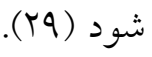

توسـعه تـيم هـاى ورزشـى و ميزبـانى رويــادهاى بـين المللسى از راهبردهـاى بدسـت آمـده در ايـن تحقيـق جهـت توسعه دييلماسـى ورزش در نيروهــاى مسـلح اسـت. بـا مـرور سـخنان مقــام معظـم رهبـرى بـهـ اهميـت ايـن راهبـرد در توسـعه دييلماسـى ورزش در نيروهـاى مســلح بـيش از يـيش يسى مسى بـريم. ايشـان مسى فرماينــ "هـيج اشـكالى نـدارد شـما (در سـازمان بسـيج) تسيم هـاى ورزشسى تشـكيل بدهيـا و ايسن تسيم هـا را بـه رده هـاى بـالاى قهرمـانى

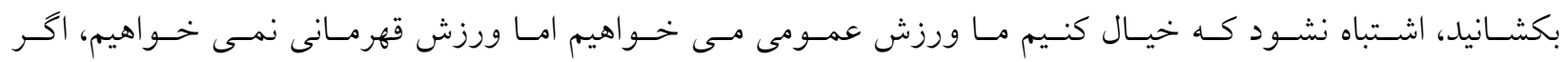

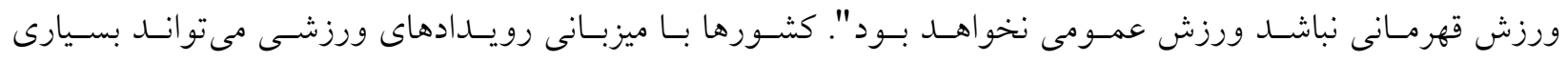

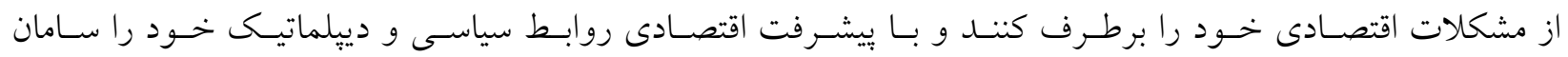

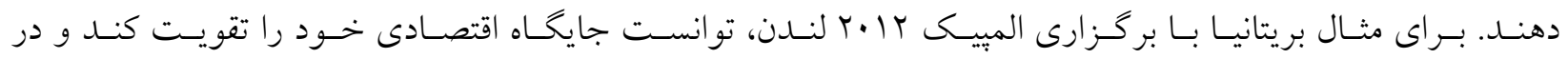

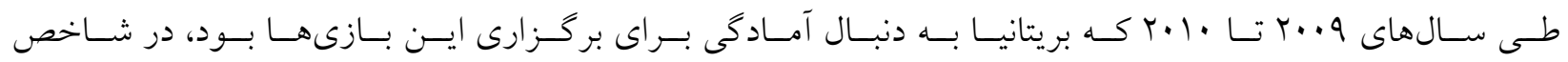
صادرات، مهاجرت، سرمايه كذارى، فرهنگ، گردشخرى و مردم جزو شش دولت برتر دنيا قرار گرفت. بسيارى از كشورها به تازكى هزينهاى خود را در بخش ورزش قهرمانى افزايش داده اند. تعداد قابل توجهى از كشورها نيز براى ميزبانى رويدادهاى بزرى ورزشى كانديد شده و اين كشورها به طور جشمخيرى افزايش يافته اند. جراكه براى به دست آوردن اعتبار بين المللى در يك سطح ورزشى جهانى بهتر از به كارگيرى قدرت نظامى و اقتصادى است. ريج 


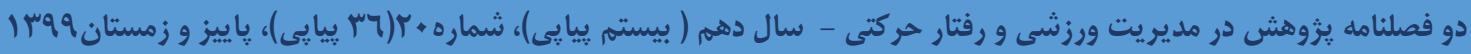

(ع (Y. مى نويسد كشور كو جك قطر شديدا در حال سرمايه كذارى در بخش ورزش است. كشور ميزبان رويدادهاى ورزشسى معتبر و بزرى مانند بازى هاى آســيايى و جام جهانى فوتبال به دنبال ترويج ورزش قهرمانى و موفقيت ورز شكاران نخبه خود هـ ستند و در با شگاه هاى ورز شى معروف ديكر كشورها سرمايه كذارى مى كنند. اين كشور ورزش را در سيا ست خارجى خود به عنوان ابزارى براى ايجاد روابط بيشتر براى به د ست آوردن قدرت نرم و امنيت

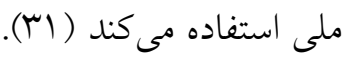

مديريت راهبردى از جمله راهبردهايى است كه نيروهاى مسلح جهت تو سعه دييلماسى ورزش مى تواند از آن استفاده كند. حال سوالى كه يِي مى آيد اين ا ست كه در محيط سرا سر متغير بين المللى ورزش جّكونه مىتواند براى كشور نقش ديهماسى ورزشى را به كونهاى بازى كند كه سياستها و اهداف ملى آنها تحقق يابد؟ صاحبنظران بر اين باورند كه مديريت اســراتزيك، مديريت خاص دوران بحران و دوره تغييرات سـريع محيط درونى و بيرونى ســازمان اســت. مديريت در جنين وضــع دشـوار و نايايدارى بيش از هر خيز به تفكرى خلاق، ذهنيتى كشــوده براى كسـب اطلاعات، شـامهاى تيز براى دريافت علائم خطر، بينشـى آينده نخر و برنامهريز و برخوردى واقع گرا و منطقى نياز دارد. مديريت استراتزيك راه و روش ثابت و تغيير تايذيرى نيست؛ بلكه خود روش ساز است. مجموعهاى از دستور العملهاى دائمى ني ست؛ بلكه خود رويههاى كار را در عمل مى آموزد. نيروهاى مـ سلح جمهورى ا سلامى ايران جهت تو سعه دييلما سى ورزشسى بايد نخاه ويزه به مديريت راهبردى به ويزه در تدوين راهبردهاى هدفمند و بلند مدت در ورزش قهرمانى خود دا شته و تهيه نق شه راه جهت بهره بردارى حداكثرى از اين فر صت با كسب كر سى هاى تاثير كذار در سيزم دا شته تا بتواند در جهت تو سعه دييلماسى ورزش خود نهايت بهره را داشته باشند و مديريت راهبردى را به عنوان راهبردى موثر جهت توسعه دييلماسى ورزشى به كار گيرند.

در دييلماسـى راههاى زيادى براى افزايش وجهه و اعتبار بخشى وجود دارد. در جهان بس از جنگ سـرد، ورزش منبع طبيعى وجهه و اعتبار اسـت. معناى اين جمله اين اسـت كه در دنياى كنونى و در فقدان بازى هاى قدرت عصـر جنگ سـرد، وجهه تنها هدفى اسـت كه دولت ها براى بدسـت اوردن ان تلاش مى كنند و ورزش يكى از شـيوههاى متعددى است كه كسب وجهه از طريق ان حاصل مى شود (T). كوبيركى(Y.IV) در تحقيقى با عنوان دييلماسى ورزش نروز، به بررسى دييلماسى ورزشى آن كشور و برر سى تاثير آن بر نام تجارى بين المللى اين كشور برداخته است. محقق در اين تحقيق، اصطلاح "دييلماسى ورزشى" را تعريف مى كند و تلاش مى نمايد تا استراتزى دييلماسى عمومى كشور نروز را مشخص كند و به دنبال تجزيه و تحليل روش هاى استفاده شده در دييلماسى ورزشى نروز است. محقق در اين تحقيق به اين نتيجه رســيد كه ديبلماســى ورزش به عنوان عاملى در بهبود وجهه و اعتبار نام تجارى كشــور نروز نقش دارد. 


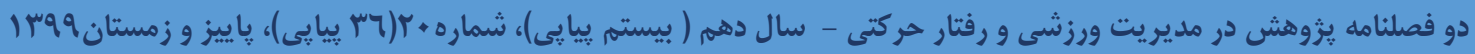

بنابراين موفقيت در رويدادهاى ورزشـى نه تنها باعث افزايش برند ملى نيروهاى مســلح كثــور مى شــود بلكه از اين فر صت مى توان در جهت ترويج شعار سيزم كه صلح و دو ستى از طريق ورزش است، وجهه و اعتبار بيشترى براى كشور بدست آورد (T).

از ديخر راهبردهاى ذكر شده تو سط نخبشان در تحقيق حاضر يزوهش و نوآورى است. نيروهاى مسلح جهت تو سعه دييلماسـى ورزش بايد به امر بززوهش و نو آورى توجه خاص داشـته باشـــ و از طريق ارتباط و تعامل هدفمند با مراكز دانشـاهى، علمى تحقيقاتى و انجام يزوهش و تحقيقات بنيادى و كاربردى در حوزه هاى مختلف ورزشسى، ايجاد بانك اطلاعاتى جامع و به روز ورز شى، به ويزه سيزم و همجنين ميزبانى رويدادهاى ورزشى از جمله مجمع عمومى سيزم و همايش هاى علمى به همراه ايجاد و باز سازى زير ساخت هاى ورز شى و تو سعه با شخاهها و پايشاههاى قهرمانى جهت جذب بيشتر ورزشكاران براى حضورى بهتر در رويدادهاى ورزشى جهت كسب افتخار و مدال با تشويق مناسب آنان در تو سعه دييلماسى ورزشى كمك نمايد و در جهت تو سعه ديبلماسى ورزش نيروهاى مسلح كام بردارند. ازنظر كلاد اسماج مدير فروش اقتصاد جهانى در داوس، در عصر كنونى دولتها بر اساس ميزان توانايى و دانش خود قضاوت مى شوند و يكى از جالشهاى موجود، تبديل اطلاعات با حجم بالا است كه تو سط شبكه ها و رسانهاى جهانى منتشر مى شود و به دانش و اطلاعات ارزشمند جهت تحقق اهداف يك سازمان ازجمله دستخاههاى دييلماتيك نيازمند است (عَ) بيامدهايى كه راهبردهاى يُوهش با اثرات تعاملى شـــرايط على، عوامل زمينهاى و مداخله كر ايجاد مى كنند، عبارتند از: تو سعه صلح و دو ستى، تو سعه تعاملات بين المللى، دستاوردهاى فرهنخى و اجتماعى، توسعه آمادكى جسمانى كاركنان نيروهاى مسلح، تو سعه ورزش قهرمانى و حرفه ای، تو سعه زير ساخت هاى ورزشى و كاهش انزواى سياسى و تحريم

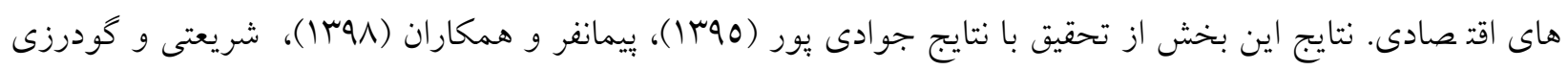

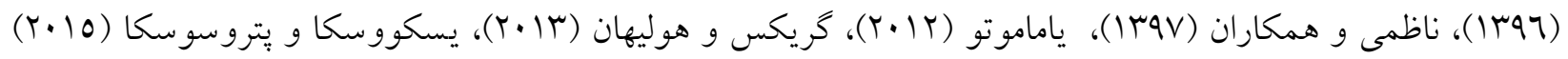

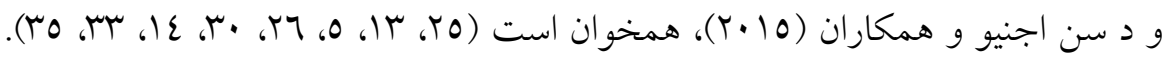
از بيامدهايى كه در نتيجه تو سعه ديِلما سى ورز شى در نيروهاى مـسلح انتظار مى رود، تو سعه صلح، دو ستى و امنيت است. برقرارى صلح و امنيت بين المللى از كهن ترين آرمانهاى بشر بوده است. در اين زمينه مطالعات متعدد حاكى از نقش يررنخ ورزش در تو سعه صلح، روابط دوستانه و امنيت بين كشورها مى باشد. د سن اجنيو و همكاران (10 (Y) از دانشگاه كاتالونيا و ياميو فاربا اسيانيا در مطالعه خود به بررسى و تجزيه و تحليل اقدام تور صلح باشگاه بارسلونا در سال

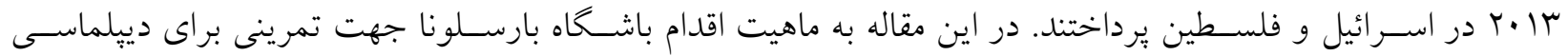
ورزشى يرداخته شده است (ro). 


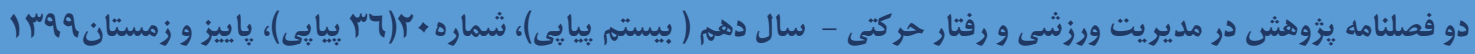

از ديخر بيامدهاى توسعه دييلماسى ورزش در نيروهاى مسلح، توسعه تعاملات بين المللى بيان شده است. امروزه تلاش در جهت توسـعه تعاملات بين المللى براى كشـورها به عنوان يك اصـل اجتناب نايذير در همه عرصسه هاى اقتصـادى، امنيتى، سيا سى و ... يذيرفته شده است. تو سعه تعاملات بين المللى كشورها مى تواند باعث رونق اقتصاد، ثبات امنيت، ارتقاء سطح سلامت، ذشاط و شادابى جامعه و ساير حوزه هاى ديخر گردد. تعامل بين نظاميان با برگزارى رويدادهاى ورز شى زمينه ساز دو ستى و نزديكى بيشتر بين آنان شده و اين امر در رفع خصومت ها و دركيرى ها بسيار موثر مى با شد. كشورها براى برون رفت از انزوا و يا تحريم هاى اقتصادى و سيا سى تلاش مى نمايند تا ارتباطات خود را در حوزه هاى بين المللى تو سعه داده و اقتلدار و توان خود را به نمايش بخذارند و لذا توسعه مراودات ورزشى بين كشورها و نظاميان زمينه ساز تعاملات در ساير عرصه ها مى كردد.

از ديخر ييامدهاى توسعه دييلماسى ورزشى در نيروهاى مسلح دستاورد هاى فرهنكى و اجتماعى تعيين شد. همراه شدن دييلماسى ورزشى با دييلماسى فرهنگى مىتواند از جمله مؤلفه هاى مولد قدرت نرم باشند. ورزش بسترى مناسب براى ارائه و ظهور خرده فرهنگ هاى كشورهاى مختلف به ويزه ميزبانان رويدادهاى بزرگ ورزشى است. در واقع كشورها از طريق نمايش فرهنگ خود در رويدادهاى بزرگ ورز شى به قبض و بسط جايگاه خود در عر صهُ بين الملل مى بردازند. جذابيت هاى روز افزون ورزش و كسـانى كه در اين حوزه فعاليت مى كنند باعث شـده اسـت تا ورزش به عنوان بسـتر منا سبى براى عر صه ارزش ها و فرهنگ هاى يك ك شور به ك شورها و فرهنگ هاى ديگر تبديل شود. ورزش و سيله مناسـبى اسـت كه قدرت نرم يك كشـور از طريق آن مى تواند به طور كسـترده تر، بيشـتر و عميق تر از آنجهه توسـط مبادلات فرهنكى معمول صورت مى گيرد، منتقل شود (YT). ي سكوو سكاو يترو سو سكا (10 (Y) در تحقيق با عنوان "دييلماسى ورز شى: تو سعه و عمل " بيان داشتند كه دييلما سى ورزشى، به عنوان بخش كاملى از دييلماسى عمومى، در روابط بين المللى مدرن عمل مى كند. در اين تحقيق محققان به اين نتيجه رسـيد كه دييلماسـى ورزشسى دسـتاوردهاى فرهنكى و اجتماعى مشـخصى براى كشـورها به همراه دارد. ديبلماسسى ورزشسى تأثير مثبى در بهبود درى عمومى از كشورها، ترويج نقوذ سياسى كشورها و كسترش فرهنگ و ارزش هاى آنها و نيز تقويت صلح دارد (سب). از ديخر ييامدهاى توسعه دييلماسى ورزش در نيروهاى مسلح، توسعه آمادكى جسمانى كاركنان نيروهاى مسلح بود. نكته اى كه اهميت زيادى براى نيروهاى مسلح برخوردار است. نيروى مسلح، نهادى اجتماعى است كه اقتدار آن به شكل مستقيم و غيرمستقيم در بيشرفت و ترقى ديكر نهادهاى اجتماعى مؤثر است. يكى از عناصر موفقيت نيروهاى مسلح در انجام ماموريت هاى محوله، داشتن آمادكى جسمانى و برخوردارى كافى از قابليت هاى لازم براى استفاده از بدن در موقعيت هاى مختلف مى باشد. اهميت تربيت جسمى و روحى نيروها به رغم ييشرفت تكنولوزى جنگ و سلاحهاى فوق مدرن،

\section{https://jrsm.khu.ac.ir/}




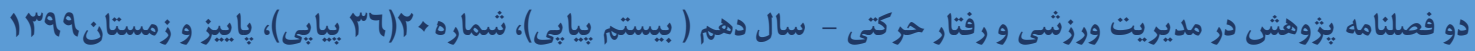

اهميت توانيى روحى وجسمى نيروهاى مسلّح به عنوان يك ضرورت يايدار براى نيروهاى مسلّح همجنان دررأس برنامهاى نظاميان مىباشد. به همين دليل در كشورهاى دنيا جايخاه ويزهاى براىتربيت بدنى و ورزش در نيروهاى مسلّح در نظر كرفته شده است.

تو سعه زير ساخت ها، تو سعه ورزش قهرمانى و حرفه اى، امكانات و تجهيزات ورز شى، افزايش سرمايه كذارى بخش خصوصى، اشتغالزايى، توريست ورزشى بيامدهايى است كه دستخاه ديبلماسى ورزشى فعال مى تواند براى هركشورى به ارمغان آورد. بيامدى كه ياماموتو (Y (T) در مطالعه خود اينخو نه بيان مى كند كه مفهوم توســعه ورزش به منظور بنا نهادن يك دولت بر يك فرهنگ ورزشسى قوى در دسـتور كار دولت زاين قرار دارد. مطالعات شـوراى ارويا كه بوسـيله كميسيون ارويايى در سال 1999 منتشرشد نشان مىدهد كه توسعه ورزش و زيرساخت هاى ورزشى اثر مهمى بر GNP و استخدام و اشتغال دارد. لذا وقتى ورزش و دييلماسى ورزشى در سياست كلان دولتها قرار گرفت، زمانى كه توسعه روابط بين الملل از طريق ورزش دغدغه دولتمردان شــد بيامدهاى ورزشــى آن ظهور خواهد كرد. اما اين بيامدها كدام

$$
\text { بيشتر از ديخرى براى كشور اهميت دارد؟ }
$$

كاهش انزواى سياسى و تحريم هاى اقتصادى از ييامدهاى تو سعه ديبماسى ورزش نيروهاى مسلح تعيين شد. تحريم هاى اقتصادى يكى از ابزارهاى دييلما سى اجبار است كه ورزش به مثابة ارزش مشترى جهانى مىتواند تجليخاه تقابل كشورهاى متخاصم و متجاوز در مقابل يكديخر باشد. كشورها از بستر ورزش به منظور اعتراض خود ذسبت به رفتار جامعd جهانى يا به طور خاص كشـورى متجاوز عليه خود اسـتفاده مى كنند. كريكس و هوليهان (T/.T) از دييلماسىى

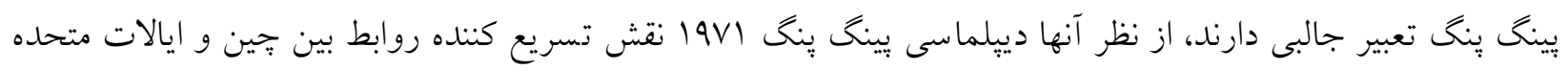
امريكا داشته است. دييلما سى بينگ ينخ از انزواى بيشتر جين و آمريكا در برابر يكديخر كاسته و منجر به روابط بيشتر آنها با يكديخر شده ا ست. بنابراين ايجاد بـ ستر هاى منا سب براى ارتباط بي شتر ورز شى بين نيروهاى نظامى كشورها مى تواند باعث كاهش انزواى سياسى و حتى تحريم ها گردد. قابل ذكر ا ست با توجه به اينكه تاكنون در سطح نيروهاى مسلح در خصوص دييلما سى نظامى و همجنين ديبلما سى ورز شى تحقيقى صورت نخرفته است و از سوى ديكر در سطح مراكز علمى كشور هم در حوزه دييلما سى نظامى و ورزشى نيروهاى مسلح تحقيقاتى انجام نشده است و بيشتر يزوهش هاى انجام شده نيز در حوزه هاى دييلماسى عمومى و ورزشى مى باشد. اكثر نتايج تحقيقات انجام شده همسو با نتايج بدست امده در تحقيق حاضر بوده و ناهمخوانى در

$$
\text { تحقيقات بسيار اندى به خشم خورده است. }
$$

\section{https://jrsm.khu.ac.ir/}




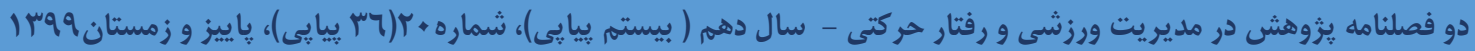

جيزى كه در اين بخش مورد توجه قرار گرفت طراحى الكويى راهبردى بود كه بتواند به توسـعه دييلماسى ورزشى در نيروهاى مسلح ج.ا. ايران كمك نمايد. با توجه به مدل بيشنهادى توسعه دييلماسى ورزشى در نيروهاى مسلح (شكل () مشاهده مى شود، اين مدل براى تو سعه دييلماسى ورزش در نيروهاى مسلح داراى شرايط على، عوامل زمينه اى، عوامل مداخله گر، راهبرد و ييامد ها است. نيروهاى مسلح جمهورى اسلامى ايران در جهت تو سعه دييلماسى ورزش بايد شر ايط على، عوامل زمينه ایى و مداخله كر را كنترل كرده و به آنها توجه داشته باشند و با تمركز بر آنها راهبردهاى منا سبى كه در اين تحقيق مشـخص شـد را به كار گيرند تا از طريق به كار گيرى اين راهبردها به بيامدهاى مدنظر دسـت يابند. از آنجا كه عوامل مختلفى به تقويت نيروهاى مســلح جمهورى اسـلامى ايران كمى مى كند، از جمله بركزارى مانورهاى رزمى مشترى با كشورهاى ديخر، بركزارى دوره هاى آموز شى مشترى و ساير برنامه هايى كه به صورت مشترى مى تواند بركزار شــود، دييلماســى ورزش نيز مى تواند به برقرارى ارتباط بيشــتر بين كشــورهاى مختلف كمك نمايد و ارتباطات ك شورها را تلطيف بخ شيده و زمينه ساز برقرارى ارتباط بي شتر بين نظاميان كشورهاى مختلف در زمينه هاى ديخر را فراهم كند. اين ارتباطات ميان نظاميان كشـورهاى مختلف زمينه سـاز ارتباط بهتر كشـورها مى شـود و منجر به توســـه دييلماســى كشــور مى كردد. آنجهه محقق به عنوان نظريه خود در تحقيق عنوان مى كند "اهميت بخشــى به ديّما سى ورزش نظاميان به عنوان ابزارى جهت تقويت دييلما سى نظامى در ساير حوزه هاى ماموريتى نيروهاى م سلح و به تبع آن تو سعه ديڤلما سى عمومى جمهورى ا سلامى ايران" همين مو ضوع رانشان مى دهد. در واقع هدف غايى توسعه ديبلماسى ورزش در نيروهاى مسلح جمهورى اسلامى ايران توسعه دييلماسى جمهورى اسلامى ايران است. جيزى كه كشور ما امروزه با توجه به مسائل و مشكلات سياسى، اقتصادى، اجتماعى و ... بيش از بيش به آن نياز دارد. تحقيق حاضر، توسعه دييلماسى ورزشى در نيروهاى مسلح را بدون توجه به سازمانهاى تابعه (ارتش، سباه، نيروى انتظامى و وزارت دفاع و يشـتيبانى نيروهاى مسـلح) بررسـى نموده اسـت، لذا به محققين آينده بيشــنهاد مى كردد در تحقيقات جداكانه اى توسـعه دييلماسـى ورزش در سـازمانهاى تابعه نيروهاى مســلح (ارتش، سـياه، نيروى انتظامى) را برر سى كنند. همجنين با توجه به اينكه تحقيق حاضر به اولويت بندى شرايط على، عوامل زمينه اى، عوامل مداخله گر، راهبرد و بيامد نبرداخته است به محققين آينده بيشنهاد مى گردد به اولويت بندى اين عوامل ببردازند. 
1. Rooney, P. Sport for Development and Peace: the case of Northern Ireland. NUI Galway. 2012;1-69.

r. Nik Ain, E. Assessing the Impact of Media on the Nature of Iranian Man. Psychological Operations Studies. 2009; No. 23 (Persian).

r. Sabilan Ardestani, H. Psychological Operations and Media Diplomacy. Psychological Operations Studies. 2004; No. 7. (Persian).

₹. Ghorbani, N. Investigating the Challenges of Iranian Public Diplomacy in the Persian Gulf Region (Case Study: Bahrain and Iraq). Thesis, Faculty of Law and Political Science. University of Tehran, Tehran, Iran. 1391 (Persian).

-. Shariati, M., Goodarzi, M. Structural Modeling (SEM) of Sports Diplomacy Components in the Development of International Relations of the Islamic Republic of Iran. New Approaches in Sports Management. 2017; 5;16. (Persian).

7. Murray S. The two halves of sports-diplomacy. Diplomacy \& statecraft. 2012 Sep 1;23(3):57692.

v. Nicholson M, Hoye R, Houlihan B, editors. Participation in sport: International policy perspectives. Routledge; 2010 Sep 6.

^. Baran Cheshmeh, M. A. Introduction to the International Military Sports Council (SEISM). NAJA Deputy for Education and Training Publications. 2014; First Edition. (Persian).

9. Ghadami, M., Mostafavi, H. Presenting the operational model of cultural diplomacy of the Islamic Republic of Iran. Journal of Cultural Management. 2009; 5(3), 61-83. (Persian).

1. Yani DR. SPORTS DIPLOMACY AS THE ALTERNATIVE OF RECONCILIATION FOR SOUTH KOREA-NORTH KOREA AND THE PROSPECT OF REUNIFICATION.

1). Côme T, Raspaud M. Sports diplomacy: A strategic challenge for Qatar. Hermès, La Revue. 2018(2):169-75.

Ir. Bazargan, A. Introduction to Qualitative and Mixed Methods: Common Approaches in Behavioral Sciences. Didar Publishing. 1389; Second Edition. (Persian).

1r. Peymanfar, M. H, Elahi; A R, Sajjadpour, MK, Hamidi, M. Explaining Sports Diplomacy Using a Paradigm Model: A Qualitative Study. Journal of Sports Management. 2019; 11;1, 59-75. (Persian).

I . Grix J, Houlihan B. Sports mega-events as part of a nation's soft power strategy: The cases of Germany (2006) and the UK (2012). The British journal of politics and international relations. 2014 Nov;16(4):572-96.

10. Porteux JN, Choi KJ. Hallyu as sports diplomacy and prestige building. Culture and Empathy. 2018;1(1-4):70-87.

17. Dubinsky Y. From soft power to sports diplomacy: A theoretical and conceptual discussion. Place Branding and Public Diplomacy. 2019 Sep 1;15(3):156-64.

Iv. Mahanta, K., \& Deshpande, M. Sports Diplomacy and International relation: A case study of India. journal of Politics \& International Relations. 2019; 12(8), 36-57

1^. Park MK. Long Shot: The Prospects and Limitations of Sports and Celebrity Athlete Diplomacy. InMedia. The French Journal of Media Studies. 2017 Dec 19(6). 
19. Jankovic S. Enhancing international dispute settlement: the role of sports diplomacy. International Journal of Diplomacy and Economy. 2017;3(3):264-78.

$r \cdot$. Humphrey J. No holding Brazil: football, nationalism and politics. Off the Ball: The Football World Cup. 1986:127-39.

$r$. Dauncey H, Hare G, editors. France and the 1998 World Cup: The national impact of a world sporting event. Taylor \& Francis US; 1999.

$r$ r. Kobierecki MM. Ping-Pong Diplomacy and its Legacy in the American Foreign Policy. Polish Political Science Yearbook. 2016;45(1):304-16.

r. Martynenko SE, Trusova AA, Cherniaev MS. Ping-Pong Diplomacy: Impact on the Establishment of Sino-US Relations. Vestnik RUDN. International Relations. 2019 Dec 15;19(1):139-47.

$r$ 纟. Yazdan Fam, M. Strategic Environment of the Islamic Republic of Iran: Military-Security Issues and Trends. National Security Watch. 2014; 24-25. (Persian).

ro. Javadipour, M. J. Investigating the issues and problems of the country's sports diplomacy with emphasis on advancing the goals of cultural-social policies and foreign relations, Basij Studies and Research Institute. Humanities Studies and Research Center. 2015. (Persian).

r7. Nazemi, M. Designing an Optimal Model of Iranian Sports Diplomacy. PhD Thesis in Sports Management. Faculty of Physical Education, Islamic Azad University. 2016. (Persian).

rv. Jarvie G. Murray S, Macdonald S. Promoting Scotland, diplomacy and influence through sport. Scottish Affairs. 2017 Feb;26(1):1-22.

rA. Siburian EE, Afriansyah A. SPORT DIPLOMACY AND STATE SOVEREIGNTY: CASE STUDY ON INDONESIA'S EFFORT TO GUARD THE SOVEREIGNTY OF PAPUA. Yustisia Jurnal Hukum. 2018 Apr 1;7(1):58-84.

r.. Hass, J., Grassmann, D. More than a Game - Sport in Foreign Policy ,http://www.ifa.de/en/culture-and-foreign-policy/research-and-dialogue/research programme /more-than-a-game-sport-in-foreign-policy.html. 2014.

$r \cdot$. Yamamoto MY. Development of the sporting nation: sport as a strategic area of national policy in Japan. International journal of sport policy and politics. 2012 Jul 1;4(2):277-96.

$r$. Reiche D. Investing in sporting success as a domestic and foreign policy tool: the case of Qatar. International journal of sport policy and politics. 2015 Oct 2;7(4):489-504.

r. Kobierecki MM. The commonwealth games as an example of bringing states closer through sport. Physical Culture and Sport. Studies and Research. 2017 Mar 1;73(1):36-43.

r. Ushkovska M, Petrushevska T. Sports Diplomacy: Development and Practice. Research in Kinesiology. 2015 Jun 1;43(1):89-93.

$r$. Asad Beigi, M., Vahidi, H. Evaluating the Effect of Knowledge Creation on Competitive Advantage in Karafarin Bank. Smart Business Management Studies. 1392; 6 (Persian).

ro. de-San-Eugenio J, Ginesta X, Xifra J. Peace, sports diplomacy and corporate social responsibility: A case study of Football Club Barcelona Peace Tour 2013. Soccer \& Society. 2017 Nov 10;18(7):836-48.

ฯ. Sabbaghian, A. Sports Diplomacy. Cultural Studies \& Communication. 2015; No. 63 (Persian). 